E-Jurnal Ekonomi dan Bisnis Universitas Udayana 8.3 (2019): 235-258

\title{
Peramalan Indikator Mikro Kinerja \\ Komoditas Strategis Perkebunan Dengan Metode ARIMAX \\ (Autoregressive Moving Average Exogenous Variabel)
}

\author{
Bayu Kharisma \\ Departemen Ilmu Ekonomi, Fakultas Ekonomi dan Bisnis, Universitas Padjadjaran \\ Jl. Dipati Ukur No. 35 Bandung, 40132, Indonesia \\ Email : bayu.kharisma@unpad.ac.id
}

\begin{abstract}
Abstrak
Tujuan penelitian ini adalah untuk melakukan peramalan (forecasting) berbagai indikator mikro kinerja komoditas strategis perkebunan yaitu kopi, kakao, lada dan tebu di Indonesia selama periode 2019-2045. Metodologi yang digunakan dalam penelitian ini adalah ARIMAX (autoregressive moving average exogenous variabel). Hasil penelitian menunjukkan bahwa produksi lada cenderung mengalami penurunan. Hal yang sama terjadi pada hasil peramalan luas areal lahan lada yang cenderung terus menurun, sedangkan produktivitas lada relatif stabil. Sementara itu, hasil peramalan produksi komoditas kopi, luas areal kopi dan tingkat produktivitas terus naik. Hasil peramalan terhadap produksi tebu cenderung meningkat, meskipun fluktuatif. Sama halnya dengan pola produksi dan luas areal tebu, dimana produktivitas juga mengalami peningkatan. Peramalan produksi kakao Indonesia berfluktuasi dan cenderung meningkat selama 20192045. Kondisi yang sama terjadi pada luas areal kakao yang terus meningkat. Terakhir, hasil peramalan terhadap tingkat produktivitas kakao cenderung naik, meskipun mengalami fluktuatif.
\end{abstract}

Kata Kunci : proyeksi, indikator mikro kinerja komoditas strategis perkebunan, ARIMAX, produksi, luas areal, produktivitas

\begin{abstract}
This paper aims to forecast various micro indicators of the performance of plantation strategic commodities, namely coffee, cocoa, pepper and sugar cane in Indonesia during the period 2019-2045. The methodology used in this paper is ARIMAX (exogenous autoregressive variable moving average). The results showed that pepper production tended to decrease. The same thing happened in the prediction of the area of pepper land which tended to continue to decline, while pepper productivity was relatively stable. Meanwhile, the projection of coffee commodity production, coffee area and productivity levels continue to rise. The projection of sugarcane production tends to increase despite fluctuations. Similar to the pattern of production, the area of sugarcane and productivity also increased. The projection of Indonesian cocoa production fluctuates and tends to increase during 2019-2045. The same conditions occur in the area of cocoa that continues to increase. Finally, the level of cocoa productivity is rising even though it tends to be volatile.
\end{abstract}

Keywords: projections, micro indicators of plantation strategic commodity performance, ARIMAX, production, area, productivity 


\section{PENDAHULUAN}

Sektor perkebunan merupakan salah satu penyumbang devisa terbesar negara melalui ekspor berbagai komoditas perkebunan. Hal ini disebabkan oleh karena beberapa komoditas perkebunan yang ada di Indonesia merupakan komoditas yang menjadi unggulan dan mampu bersaing di pasar internasional seperti kelapa sawit, kakao, kopi, karet, lada, teh, pala, dan cengkeh. Sementara itu untuk tebu dan kelapa lebih banyak digunakan untuk keperluan di dalam negeri. Kesepuluh komoditas tersebut termasuk ke dalam 10 komoditas unggulan strategis nasional yang menjadi prioritas Ditjen Perkebunan dalam pengembangannya.

Sektor perkebunan dalam perekonomian nasional pada tahun 2017 memiliki peran penting dengan kontribusi nilai tambah terbesar pada sektor pertanian (35\% dari PDB sektor pertanian) atau 437,8 triliun rupiah. Nilai tersebut mengungguli sektor pertambangan minyak, gas dan panas bumi dengan nilai PDB 390,5 triliun rupiah ${ }^{1}$. Dilihat dari penyerapan tenaga kerja, sektor perkebunan melibatkan petani dan tenaga kerja sebanyak 22,69 juta jiwa (Ditjen Perkebunan, 2017) dari 131,5 juta angkatan kerja ${ }^{2}$ atau menyerap $17 \%$ tenaga kerja dari jumlah angkatan kerja yang ada di Indonesia. Data tersebut menunjukkan peran perkebunan dalam penyediaan peluang bekerja/berusaha bagi masyarakat Indonesia, pemenuhan kebutuhan konsumsi dan bahan baku industri dalam dan luar negeri (termasuk energi terbarukan). Penciptaan nilai tambah yang begitu besar dalam sektor perkebunan dari usaha budidaya dan usaha turunan (agroindustri) di hilirnya semakin memperkokoh sektor perkebunan dalam kontribusinya terhadap perekonomian nasional.

Secara umum pengembangan komoditas perkebunan difokuskan pada 16 komoditas unggulan yaitu Tebu, Kelapa Sawit, Karet, Kelapa, Kakao, Kopi, Lada, Teh, Pala, Cengkeh, Jambu Mete, Sagu, Kemiri Sunan, Kapas, Tembakau dan Nilam. Penentuan komoditas tersebut sesuai dengan Keputusan Menteri Pertanian nomor 511/Kpts/PD.310/9/2006 tentang jenis komoditas tanaman binaan Direktorat Jenderal Perkebunan, Direktorat Jenderal Tanaman Pangan dan Direktorat Jenderal Hortikultura serta Keputusan Menteri Pertanian nomor 3599/Kpts/PD.310/10/2009 tentang perubahan lampiran I dari Keputusan Menteri Pertanian nomor 511/Kpts/PD.310/9/2006.

Arah pengembangan komoditas-komoditas tersebut dicapai melalui program peningkatan produksi komoditas perkebunan berkelanjutan dengan implementasi kegiatan seperti rehabilitasi, intensifikasi, ekstensifikasi dan diversifikasi yang didukung oleh penyediaan benih bermutu, pemberdayaan pekebun dan penguatan kelembagaan, pembangunan dan pemeliharaan kebun sumber benih, penanganan pascapanen, pengolahan, fasilitasi pemasaran, standarisasi mutu, pembinaan usaha dan perlindungan perkebunan serta pemberian pelayanan berkualitas dibidang manajemen dan kesekretariatan. Komoditas-komoditas unggulan perkebunan yang masih dalam tahap inisiasi tetap dikembangkan dan difasilitasi Ditjen. Perkebunan yang diarahkan untuk pemenuhan standar pelayanan minimum (SPM) yang meliputi penyediaan benih/ varietas unggul, pembangunan/ pemeliharaan kebun sumber benih (demplot, kebun induk, kebun entres dan lain-lain), pengendalian OPT, penanganan pascapanen, pemberdayaan pekebun, peningkatan kapasitas sumber daya insani (SDI) dan penguatan kelembagaan. Sedangkan dalam tahap penumbuhan/ pengembangan selain penguatan aspek budidaya dan perlindungan perkebunan juga difasilitasi aspek pengolahan, standarisasi mutu dan pemasarannya.

\footnotetext{
${ }^{1}$ Diolah dari data BPS tahun 2018

${ }^{2}$ Badan Pusat Statistik (BPS) menyebutkan jumlah angkatan kerja Indonesia pada Februari 2017 sebanyak 131,55 juta.
} 
Pembangunan perkebunan ke depan dihadapkan pada berbagai tantangan, seperti terjadinya berbagai perubahan dan perkembangan lingkungan yang sangat dinamis sebagai akibat dari tekanan globalisasi dan liberalisasi perdagangan, pesatnya kemajuan teknologi dan informasi, semakin terbatasnya ketersediaan sumber daya lahan, air dan energi, serta terjadinya perubahan iklim global. Dari sektor usahatani dan produksi juga masih dihadapkan pada berbagai masalah seperti kecilnya kepemilikan dan penguasaan status lahan, terbatasnya kemampuan sistem perbenihan nasional, terbatasnya akses petani terhadap permodalan, masih lemahnya kapsitas kelembagaan petani dan penyuluh, serta kurang harmonisnya kerjasama dan koordinasi antar sektor terkait pembangunan perkebunan.

Diperlukan suatu perencanaan produksi yang baik agar peran strategis komoditas perkebunan dalam sektor pertanian di Indonesia dapat dipertahankan atau bahkan ditingkatkan dengan cara menentukan arah awal dari program kerja yang harus dilakukan, berapa banyak melakukannya, dan kapan harus dilakukan. Perencanaan dalam produksi perkebunan berkaitan dengan masa yang akan datang, sehingga perlu disusun perkiraan/peramalan yang dibuat berdasarkan data masa lalu dengan menggunakan batasan asumsi dari berbagai indikator mikro kinerja perkebunan yang meliputi luas lahan, produksi (penawaran) dan produktivitas sedangkan data permintaan, harga produk, dan ekspor-impor perkebunan diperlukan sebagai variabel yang mendukung analisis indikator mikro kinerja perkebunan. Peramalan indikator mikro kinerja perkebunan pada berbagai komoditas strategis perkebunan sangat diperlukan dalam jangka menengah ( 5 tahunan) dan jangka panjang (10-25 tahunan) dalam rangka perencanaan pembangunan perkebunan yang terintegrasi dan holistik, terutama dalam hal intervensi pemerintah sebagai regulator dalam sektor perkebunan. Dengan demikian, tujuan penelitian ini yaitu untuk mengetahui peramalan berbagai indikator mikro kinerja komoditas strategis perkebunan di Indonesia sampai dengan tahun 2045 dengan pendekatan ARIMAX (autoregressive moving average exogenous variabel). Adapun, komoditas strategis perkebunan yang dimaksud meliputi: a) kopi; b) kakao; c) lada dan d) tebu

\section{METODOLOGI PENELITIAN}

Salah satu model runtun waktu yang dipandang sebagai perluasan dari model runtun waktu ARIMA adalah yang disebut sebagai model autoregressive moving average exogenous variabel (ARIMAX), yaitu model ARIMA dengan variabel exogen. Dalam model ini, faktor-faktor yang mempengaruhi tidak bebas dari indikator mikro pembangunan perkebunan, yaitu luas areal, produksi dan prroduktivitas tidak hanya dipengaruhi oleh waktu ke -t, tetapi dipengaruhi oleh variabel bebas lain pada waktu ke -t yaitu iklim yang diwakili oleh curah hujan. Dalam hal ini, diyakini bahwa curah hujan merupakan salah satu faktor yang sangat mempengaruhi berbagai komoditas perkebunan, khususnya kopi, kakao, lada dan tebu

Model ARIMAX adalah model ARIMA dengan variabel tambahan (Cryer \& Chan, 2008). Pada penelitian ini, ada variabel tambahan, yaitu variabel bebas lain pada waktu ke -t yaitu iklim yang diwakili oleh curah hujan. Selanjutnya, model ARIMAX dengan tren deterministik diberikan sebagai berikut.

$$
Y_{t}=\beta_{1} V_{1, t}+\beta_{2} V_{2, t}+\ldots+\beta_{p} V_{p, t}+\frac{\theta_{q}(B) \Theta Q^{\left(B^{S}\right)}}{\phi_{p}(B) \Phi_{P}\left(B^{S}\right)(1-B)^{d}\left(1-B^{S}\right)^{D}} a_{t}
$$

Pemodelan di atas terdiri dari variabel respon, yaitu data time series dan kalender variasi yang berperan sebagai dummy variable. Menurut Lee \& Suhartono (2010), langkah penyelesaian analisis dengan menggunakan model ARIMAX adalah sebagai berikut: 
1. Studi literatur dan mecari informasi mengenai bahan penelitian

2. Merumuskan permasalahan dan tujuan dari penelitian

3. Mempersiapkan data yang akan digunakan, baik variabel respon (deret output), variabel prediktor (deret input)

4. Membuat plot time series dari variabel respon (deret output atau $\mathrm{Y}_{\mathrm{t}}$ ).

5. Melakukan analisis data dengan metode ARIMA
a. Uji stasioneritas data
b. Menghilangkan ketidakstasioneran dalam data
c. Melakukan kembali uji stasioneritas data
d. Menaksir model sementara
e. Melakukan pemeriksaan apakah model telah memadai
f. Jika model belum memadai, kembali ke langkah 5.d dan seterusnya
g. Menggunakan model untuk peramalan

6. Melakukan analisis data dengan metode fungsi transfer

a. Identifikasi bentuk model

i. Mempersiapkan deret input dan output

ii. Prewhitening deret input: membentuk model ARIMA yang sesuai untuk deret input $\left(\mathrm{x}_{\mathrm{t}}\right)$ sehingga diperoleh deret input yang sudah white noise $\left(\alpha_{t}\right)$.

iii. Prewhitening deret output untuk mendapatkan deret output white noise $\left(\beta_{t}\right)$.

iv. Penghitungan cross-correlation dan autokorelasi untuk deret input dan deret output yang telah melalui tahap Prewhitening, (antara $\alpha_{t}$ dan $\beta_{t}$ ) atau dinotasikan CCF.

v. Penaksiran bobot respons impuls

vi. Penetapan $(b, s, r)$ untuk model fungsi transfer yang menghubungkan deret input dan output

vii. Penaksitan awal deret gangguan/noise $\left(n_{t}\right)$

viii. Penetapan $\left(p_{n}, q_{n}\right)$ untuk model ARIMA $(P n, 0, q n)$ deret gangguan $\left(n_{t}\right)$

b. Penaksiran parameter-parameter model

c. Uji diagnosis model

i. Penghitungan autokorelasi untuk nilai sisa model $(b, s, r)$ yang menghubungkan deret input dan output

ii. Penghitungan cross-correlation antara nilai sisa yang disebutkan dalam poin c(i) dengan deret gangguan yang telah dilakukan Prewhitening

d. Menggunakan model untuk peramalan

i. Peramalan nilai-nilai yang akan datang dengan menggunakan model fungsi transfer

Evaluasi model digunakan untuk melakukan pemilihan model terbaik dari beberapa kemungkinan model time series yang didapatkan. Untuk pemilihan model berdasarkan data insample, kriteria yang digunakan adalah Akaike's Information Criterion (AIC) dan Scwartz's Bayesian Criterion (SBC) (Wei, 2006).

$$
\begin{gathered}
A I C(M)=n \ln \hat{\sigma}_{\alpha}^{2}+2 M \\
S B C(M)=n \ln \hat{\sigma}_{\alpha}^{2}+M \ln n
\end{gathered}
$$

dimana

$\mathrm{M}=$ jumlah parameter

$\mathrm{n}=$ jumlah pengamatan 
Root mean square error (RMSE) juga merupakan salah satu indeks yang dapat digunakan untuk mengevaluasi ketepatan model time series yang digunakan. Lee \& Suhartono (2010) menyatakan perhitungan RMSE untuk data outsample adalah sebagai berikut:

$$
R M S E_{\text {out }}=\sqrt{\frac{\sum_{t=1}^{n}\left(Y_{t}-\hat{Y}_{t}\right)^{2}}{n}}
$$

\section{HASIL DAN PEMBAHASAN}

\section{a. Pemilihan Model Terbaik}

Untuk melakukan permalan indikator mikro pembangunan perkebunan untuk komoditas lada, kakao, tebu dan kopi tahun 2019 sampai dengan tahun 2045 dilakukan dengan pemilihan model terbaik. Pemilihan model terbaik ditentukan dari kriteria AIC, SBC dan MSE data in sampel terkecil serta dari MSE data out sampel terkecil. Kriteria pemilihan model dapat dilihat pada Tabel 1 berikut ini:

Tabel 1. Pemilihan Model ARIMAX Terbaik

\begin{tabular}{|l|l|c|c|c|c|c|}
\hline Komoditas & \multicolumn{1}{|c|}{ Indikator } & Model & AIC & SBC & RMSE in & RMSE out \\
\hline \multirow{4}{*}{ Lada } & Produksi & $\begin{array}{c}\text { ARIMAX } \\
(4,1,4)\end{array}$ & 4.21 & 5.91 & 7.12 & 6.10 \\
\cline { 2 - 7 } & Luas Areal & $\begin{array}{c}\text { ARIMAX } \\
(1,1,3)\end{array}$ & 5.78 & 5.55 & 4.78 & 4.94 \\
\cline { 2 - 7 } & Produktivitas & $\begin{array}{c}\text { ARIMAX } \\
(0,1,1)\end{array}$ & 5.92 & 5.91 & 7.90 & 6.33 \\
\hline \multirow{5}{*}{ Kakao } & Produksi & $\begin{array}{c}\text { ARIMAX } \\
(0,2,1)\end{array}$ & 9.19 & 8.10 & 7.87 & 5.91 \\
\cline { 2 - 7 } & Luas Areal & $\begin{array}{c}\text { ARIMAX } \\
(1,2,1)\end{array}$ & 9.22 & 8.89 & 8.09 & 5.11 \\
\cline { 2 - 7 } Tebu & Produktivitas & $\begin{array}{c}\text { ARIMAX } \\
(1,2,2)\end{array}$ & 9.01 & 8.61 & 7.21 & 4.31 \\
\cline { 2 - 7 } & Produksi & $\begin{array}{c}\text { ARIMAX } \\
(0,2,1)\end{array}$ & 2,92 & 5,33 & 3,33 & 5,47 \\
\cline { 2 - 7 } & Luas Areal & $\begin{array}{c}\text { ARIMAX } \\
(0,2,1)\end{array}$ & 3,12 & 5,64 & 4,01 & 5,87 \\
\hline \multirow{4}{*}{ Kopi } & Produktivitas & $\begin{array}{c}\text { ARIMAX } \\
(1,2,0)\end{array}$ & 3,56 & 5,12 & 3,78 & 5,87 \\
\cline { 2 - 7 } & Produksi & $\begin{array}{c}\text { ARIMAX } \\
(0,2,1)\end{array}$ & 6,00 & 9,22 & 5,45 & 4,13 \\
\cline { 2 - 7 } & Luas Areal & $\begin{array}{c}\text { ARIMAX } \\
(3,2,1)\end{array}$ & 7,12 & 6,43 & 4,67 & 4,22 \\
\cline { 2 - 7 } & Produktivitas & $\begin{array}{c}\text { ARIMAX } \\
(0,2,1)\end{array}$ & 3,87 & 7,40 & 5,23 & 5,00 \\
\hline
\end{tabular}

Sumber : Hasil Perhitungan

Pemilihan model pada Tabel 1 didasarkan pada nilai AIC, SBC, dan RMSE, baik untuk data in-sample maupun data out-sample yang paling kecil dari keseluruhan kemungkinan model yang telah diestimasi sebelumnya.

\section{b. Komoditas Lada}




\section{Sisi Produksi}

Berdasarkan Gambar 1 menunjukkan bahwa peramalan untuk produksi lada pada tahun 2019-2045 cenderung mengalami penurunan. Turunnya produksi lada tidak lepas dari anjloknya harga, mau tidak mau akan berdampak pada menurunnya pula tingkat perekonomian para petaninya. Jika hal itu yang terus terjadi, tidak menutup kemungkinan lama-kelamaan jumlah para petani lada akan terus berkurang karena beralih menanam komoditas lain atau mencari pekerjaan lain demi mempertahankan hidup keluarganya.

Selain itu, dibarengi oleh melemahnya daya saing akibat rendahnya produktivitas dan mutu lada lokal. Pada tahun 2013, tingkat produktivitas lada Indonesia hanya sekitar 0,5 ton per hektar dari yang sebelumnya pada masa kejayaan sempat mencapai 2 ton per hektar, sedangkan produktivitas lahan lada di Vietnam sangat tinggi yakni sekitar 3,2 ton per hektar. Selanjutnya budidaya lada nasional hampir seluruhnya dikelola oleh Perkebunan Rakyat yang umumnya masih belum menerapkan teknologi budidaya secara tepat dan disertai oleh mutu hasil rendah karena panen dan pengolahan masih bersifat tradisional. Oleh karena itu, sangat rentan terhadap serangan hama penyakit sehingga produksi yang diperoleh tidak optimal (Marlinda, 2008).

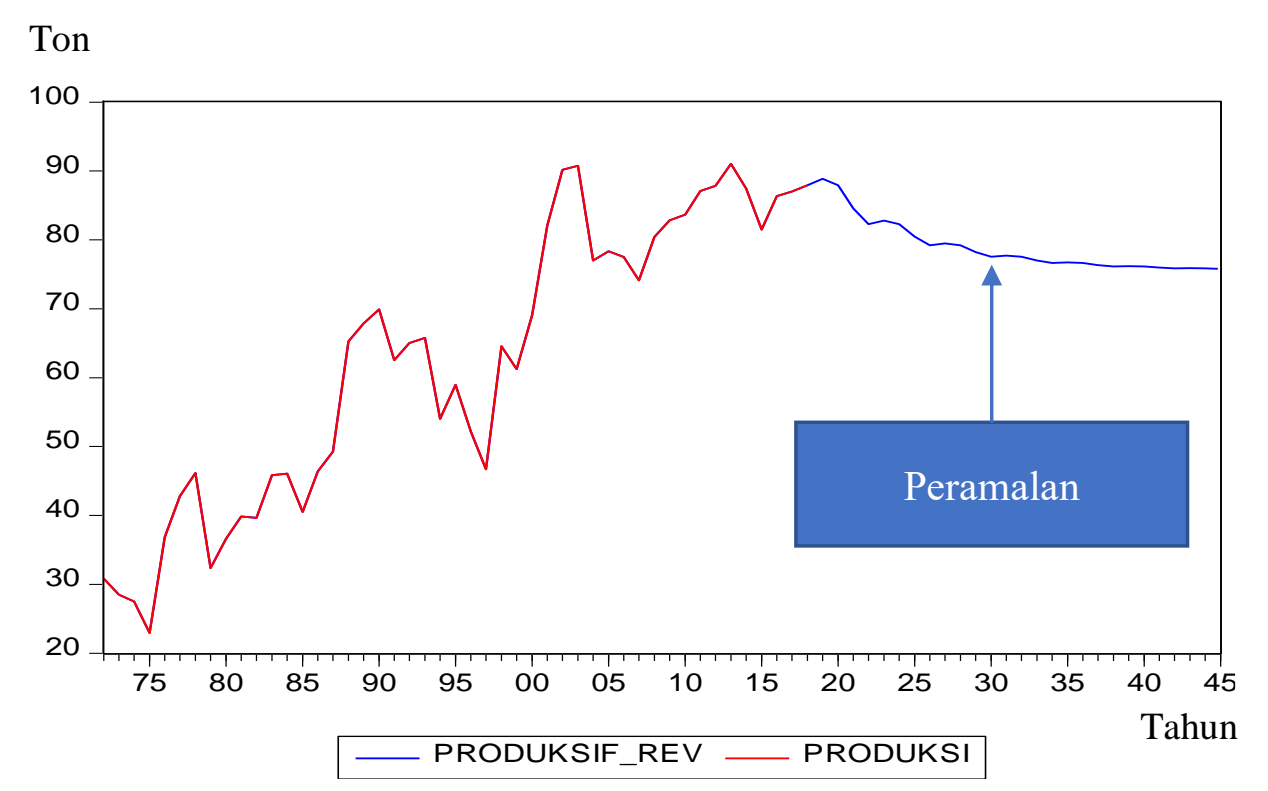

\section{Gambar 1. Peramalan Komoditas Lada Periode Tahun 2019-2045}

Sementara itu, jika dilihat dari peramalan berdasarkan skenario pesimis, moderat dan optimis pada derajat kepercayaan 95 persen dapat diketahui bahwa produksi lada di Indonesia pada tahun 2045 cenderung mengalami penurunan yaitu 43.530 ton, 75.790 ton dan 108.060 ton. Lebih jelasnya dapat dilihat pada Tabel 2 dibawah ini. 
Tabel 2. Peramalan Komoditas Lada Tahun 2019-2045 dengan Skenario Pesimis, Moderat dan Optimis (Ton)

\begin{tabular}{|c|c|c|c|}
\hline Tahun & $\begin{array}{c}\text { Produksi } \\
\text { Peramalan Skenario } \\
\text { Pesimis }\end{array}$ & $\begin{array}{c}\text { Produksi } \\
\text { Peramalan Skenario } \\
\text { Moderat }\end{array}$ & $\begin{array}{c}\text { Produksi } \\
\text { Peramalan Skenario } \\
\text { Optimis }\end{array}$ \\
\hline 2019 & 76.740 & 88.860 & 100.980 \\
\hline 2020 & 71.070 & 87.930 & 104.790 \\
\hline 2021 & 63.700 & 84.560 & 105.430 \\
\hline 2022 & 57.920 & 82.290 & 106.660 \\
\hline 2023 & 57.470 & $82 . .790$ & 108.110 \\
\hline 2024 & 55.710 & 82.280 & 108.850 \\
\hline 2025 & 52.740 & 80.450 & 108.170 \\
\hline 2026 & $50 . .400$ & 79.220 & 108.030 \\
\hline 2027 & 50.330 & 79.490 & 108.650 \\
\hline 2028 & 49.540 & 79.210 & 108.890 \\
\hline 2029 & 48.150 & 78.220 & 108.290 \\
\hline 2030 & 47.070 & 77.550 & 108.030 \\
\hline 2031 & 47.030 & 77.700 & 108.360 \\
\hline 2032 & 46.620 & 77.550 & 108.470 \\
\hline 2033 & 45.930 & 77.010 & 108.080 \\
\hline 2034 & 45.380 & 76.640 & 107.900 \\
\hline 2035 & 45.340 & 76.720 & 108.100 \\
\hline 2036 & 45.110 & 76.640 & 108.170 \\
\hline 2037 & 44.740 & 76.350 & 107.960 \\
\hline 2038 & 44.430 & 76.150 & 107.860 \\
\hline 2039 & 44.380 & 76.190 & 108.000 \\
\hline 2040 & 44.230 & 76.150 & 108.060 \\
\hline 2041 & 44.020 & 75.990 & 107.960 \\
\hline 2042 & 43.830 & 75.880 & 107.920 \\
\hline 2043 & 43.770 & 75.900 & 108.030 \\
\hline 2044 & 43.670 & 75.880 & 108.090 \\
\hline 2045 & 43.530 & 75.790 & 108.060 \\
\hline
\end{tabular}

Sumber : Hasil Perhitungan ARIMAX $(4,1,4)$

\section{Sisi Luas Areal}

Menurut data dari Direktorat Jenderal Perkebunan, perkembangan luas areal lada di Indonesia selama periode tahun 1972-2018 cenderung meningkat (Gambar 2), yaitu dari 45.834 ribu ha pada tahun 1972 menjadi 181.988 ribu ha pada tahun 2018. Luas areal tertinggi dicapai pada tahun 2003 sebesar 204,36 ha, namun setelah tahun 2003 luas areal lada nasional mengalami penurunan. Hal yang sama terjadi pada hasil peramalan selama tahun 2019-2045 menunjukkan bahwa luas areal lahan lada cenderung terus menurun (Gambar 2).

Penurunan luas areal ini disebabkan antara lain oleh konversi tanaman lada ke komoditas perkebunan lainnya dengan pertimbangan komoditas lain diyakini memiliki nilai ekonomis lebih tinggi. Oleh karena itu, adanya konversi terus berdampak pada luas areal lada yang ada dari tahun ke tahun semakin mengalami penyusutan. Dengan modal yang terbatas maka petani lebih memilih untuk mengalihkan usahanya ke komoditas perkebunan lainnya yang dianggap lebih memberikan keuntungan daripada lada, yang mengakibatkan terjadinya penurunan luas areal lada. Sebagai contoh kasus empiris, di daerah kabupaten Lampung menunjukkan bahwa lahan perkebunan lada menjadi areal kopi dan cengkeh yang secara tidak langsung dapat mengancam keberadaan luas areal lada di kabupaten setempat. Selain itu, terjadinya penurunan lahan lada disebabkan oleh kekeringan, serangan penyakit, dan konversi areal lada untuk pertambangan (Badan 
Pengkajian dan Pengembangan Perdagangan, 2016). Lada juga dianggap komoditi yang kurang menarik oleh para pengusaha Perkebunan Besar Swasta (PBS). Hal ini diindikasikan dengan menurunnya luas areal lada PBS (Outlook Lada, 2015).

Luas areal (Ha)



\section{Gambar 2. Peramalan Luas Areal Lahan Lada Periode Tahun 2019-2045}

Selanjutnya, apabila dilihat dari peramalan berdasarkan skenario pesimis, moderat dan optimis pada derajat kepercayaan 95 persen menunjukkan bahwa luas areal lada di Indonesia pada tahun 2045 cenderung mengalami penurunan yaitu $96.319 \mathrm{Ha}, 175.768 \mathrm{Ha}$ dan 255.216 Ha. Lebih jelasnya dapat dilihat pada Tabel 3 dibawah ini.

Tabel 3. Peramalan Luas Areal Lahan Lada Tahun 2019-2045 dengan Skenario Pesimis, Moderat dan Optimis (Ha)

\begin{tabular}{|c|c|c|c|}
\hline Tahun & $\begin{array}{c}\text { Peramalan Luas Areal } \\
\text { Lahan Skenario Pesimis }\end{array}$ & $\begin{array}{c}\text { Peramalan Luas Areal } \\
\text { Lahan Skenario Moderat }\end{array}$ & $\begin{array}{c}\text { Peramalan Luas Areal } \\
\text { Lahan Skenario } \\
\text { Optimis }\end{array}$ \\
\hline 2019 & 159.108 & 183.321 & 207.534 \\
\hline 2020 & 148.164 & 182.141 & 216.118 \\
\hline 2021 & 139.402 & 180.373 & 221.345 \\
\hline 2022 & 133.985 & 181.498 & 229.010 \\
\hline 2023 & 128.775 & 180.377 & 231.980 \\
\hline 2024 & 124.354 & 178.994 & 233.633 \\
\hline 2025 & 121.354 & 180.110 & 238.865 \\
\hline 2026 & 117.979 & 179.057 & 240.135 \\
\hline 2027 & 115.350 & 177.990 & 240.630 \\
\hline 2028 & 113.396 & 179.065 & 244.733 \\
\hline 2029 & 110.989 & 178.068 & 245.148 \\
\hline 2030 & 109.353 & 177.262 & 248.588 \\
\hline 2031 & 107.960 & 178.274 & 248.500 \\
\hline 2032 & 106.155 & 177.328 & 248.345 \\
\hline 2033 & 105.127 & 176.736 & 251.282 \\
\hline 2034 & 104.061 & 177.672 & 250.881 \\
\hline 2035 & 102.665 & 176.773 & 250.691 \\
\hline 2036 & 102.026 & 176.359 & 253.260 \\
\hline 2037 & 101.159 & 177.210 & 252.660 \\
\hline 2038 & 100.055 & 176.358 & \\
\hline & & & \\
\hline & & & \\
\hline
\end{tabular}


E-Jurnal Ekonomi dan Bisnis Universitas Udayana 8.3 (2019): 235-258

\begin{tabular}{|l|l|l|l|}
\hline 2039 & 99.669 & 176.090 & 252.510 \\
\hline 2040 & 98.928 & 176.853 & 254.777 \\
\hline 2041 & 98.040 & 176.048 & 254.055 \\
\hline 2042 & 97.819 & 175.900 & 253.981 \\
\hline 2043 & 97.158 & 176.574 & 255.991 \\
\hline 2044 & 96.437 & 175.818 & 255.199 \\
\hline 2045 & 96.319 & 175.768 & 255.216 \\
\hline
\end{tabular}

Sumber : Hasil Perhitungan ARIMAX $(1,1,3)$

\section{Sisi Produktivitas}

Salah satu faktor yang mempengaruhi penurunan produksi suatu komoditas yaitu disebabkan oleh masih rendahnya nilai produktivitas dari komoditas tersebut. Pada tahun 2013, tanaman lada di Indonesia yang hanya mampu mencapai 0,5 ton per hektar. Angka ini jauh dilampaui negara-negara lain yang justru luas areal tanamnya lebih sedikit, misalnya Vietnam. Sampai saat ini, pasokan lada terbesar di Dunia masih di dominasi oleh Vietnam yang mampu menyuplai sebesar 34,5 persen kebutuhan lada dunia. Pada tahun 2013, Vietnam mampu menghasilkan 163 ribu ton dari luas lahan 51 ribu hektar. Luasan ini kurang dari setengah luas lahan lada di Indonesia. Selain Vietnam, negara lain yang memiliki tingkat produktivitas lahan yang tinggi antara lain Rwanda, sebesar 3,9 ton per hektar, disusul Thailand sebesar 3,4 ton per hektar, Malaysia sebesar 2,5 ton per hektare dan Brasil sebesar 2,3 ton per hektare (Badan Pengkajian dan Pengembangan Perdagangan, 2016).

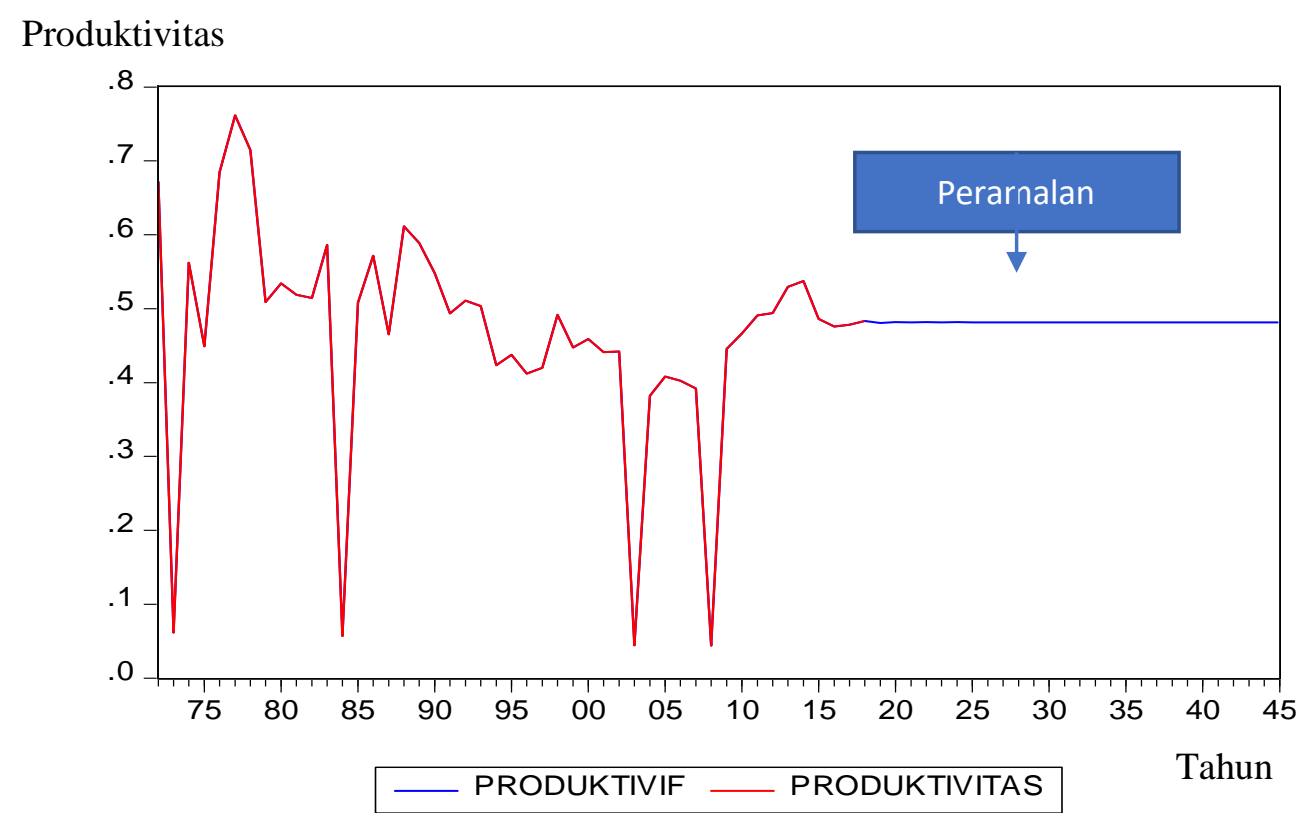

\section{Gambar 3. Peramalan Produktivitas Lada Periode Tahun 2019-2045}

Rendahnya adopsi dan diseminasi teknologi para petani lada di Indonesia, diduga menjadi salah satu faktor rendahnya tingkat produktivitas lada di Indonesia. Selain itu, perubahan iklim memberikan berdampak negatif pada produksi dan kualitas lada serta rendahnya produktivitas lada. Penyebab lainnya yaitu pengelolaan lada yang sebagian besar dilakukan oleh petani PR dengan pengetahuan teknologi budidaya yang masih rendah tanpa menggunakan bibit unggul disinyalir merupakan salah satu penyebab menurunnya produktivitas lada. Sementara itu, jika dilihat hasil peramalan selama tahun 
2019-2045 menunjukkan bahwa produktivitas lada cenderung stabil pada angka 0,48 ton per hektare (lihat Gambar 3).

Selanjutnya, apabila dilihat dari peramalan berdasarkan skenario moderat pada derajat kepercayaan 95 persen menunjukkan bahwa produktivitas lada di Indonesia pada tahun 2045 cenderung stabil pada kisaran 0,48, sedangkan melihat skenario pesimis nilainya jauh lebih kecil yaitu mencapai 0,17 dan skenario optimis cukup tinggi yaitu 0,79. Lebih jelasnya dapat dilihat dari Tabel 3 dibawah ini.

Tabel 3. Peramalan Produktivitas Lada Tahun 2019-2045 dengan Skenario Pesimis, Moderat dan Optimis (ton per hektare)

\begin{tabular}{|c|c|c|c|}
\hline Tahun & $\begin{array}{c}\text { Peramalan } \\
\text { Produktivitas } \\
\text { Skenario Pesimis }\end{array}$ & $\begin{array}{l}\text { Peramalan Produktivitas } \\
\text { Skenario Moderat }\end{array}$ & $\begin{array}{l}\text { Peramalan Produktivitas } \\
\text { Skenario Optimis }\end{array}$ \\
\hline 2019 & 0.16864 & 0.48077 & 0.79290 \\
\hline 2020 & 0.16982 & 0.48195 & 0.79409 \\
\hline 2021 & 0.16924 & 0.48138 & 0.79352 \\
\hline 2022 & 0.16951 & 0.48166 & 0.79380 \\
\hline 2023 & 0.16937 & 0.48152 & 0.79367 \\
\hline 2024 & 0.16943 & 0.48159 & 0.79374 \\
\hline 2025 & 0.16939 & 0.48155 & 0.79371 \\
\hline 2026 & 0.16940 & 0.48157 & 0.79373 \\
\hline 2027 & 0.16939 & 0.48156 & 0.79373 \\
\hline 2028 & 0.16939 & 0.48157 & 0.79374 \\
\hline 2029 & 0.16938 & 0.48156 & 0.79374 \\
\hline 2030 & 0.16938 & 0.48156 & 0.79375 \\
\hline 2031 & 0.16938 & 0.48156 & 0.79375 \\
\hline 2032 & 0.16937 & 0.48156 & 0.79376 \\
\hline 2033 & 0.16937 & 0.48156 & 0.79376 \\
\hline 2034 & 0.16936 & 0.48156 & 0.79377 \\
\hline 2035 & 0.16936 & 0.48156 & 0.79377 \\
\hline 2036 & 0.16935 & 0.48156 & 0.79378 \\
\hline 2037 & 0.16935 & 0.48156 & 0.79378 \\
\hline 2038 & 0.16934 & 0.48156 & 0.79379 \\
\hline 2039 & 0.16934 & 0.48156 & 0.79379 \\
\hline 2040 & 0.16933 & 0.48156 & 0.79380 \\
\hline 2041 & 0.16933 & 0.48156 & 0.79380 \\
\hline 2042 & 0.16932 & 0.48156 & 0.79381 \\
\hline 2043 & 0.16932 & 0.48156 & 0.79381 \\
\hline 2044 & 0.16931 & 0.48156 & 0.79382 \\
\hline 2045 & 0.16931 & 0.48156 & 0.79382 \\
\hline
\end{tabular}

Sumber : Hasil Perhitungan ARIMAX $(0,1,1)$

\section{Komoditas Kopi}

\section{Sisi Produksi}

Selama periode tahun 1980-2018 produksi kopi Indonesia cenderung terus mengalami peningkatan, yaitu dari 294.973 ton pada tahun 1980 menjadi 674.636 ton pada tahun 2018, dimana peningkatan produksi kopi tertinggi pada periode tersebut terjadi pada tahun 2008 sebesar 698.016 ton (Gambar 4). Kondisi yang sama terjadi dengan hasil peramalan selama tahun 2019 sampai tahun 2045, dimana pada tahun 2045 produksi kopi pada mengalami peningkatan yaitu 874.508 ton. Adanya peningkatan produksi kopi tersebut tidak lepas dari adanya replanting atau penanaman baru sekitar $30 \%$ dari total luas lahan kopi sebesar 1,2 juta hektare dan juga penggunaan bibit yang lebih berkualitas, meskipun adanya produksi yang terkendala akibat adanya cuaca buruk. 


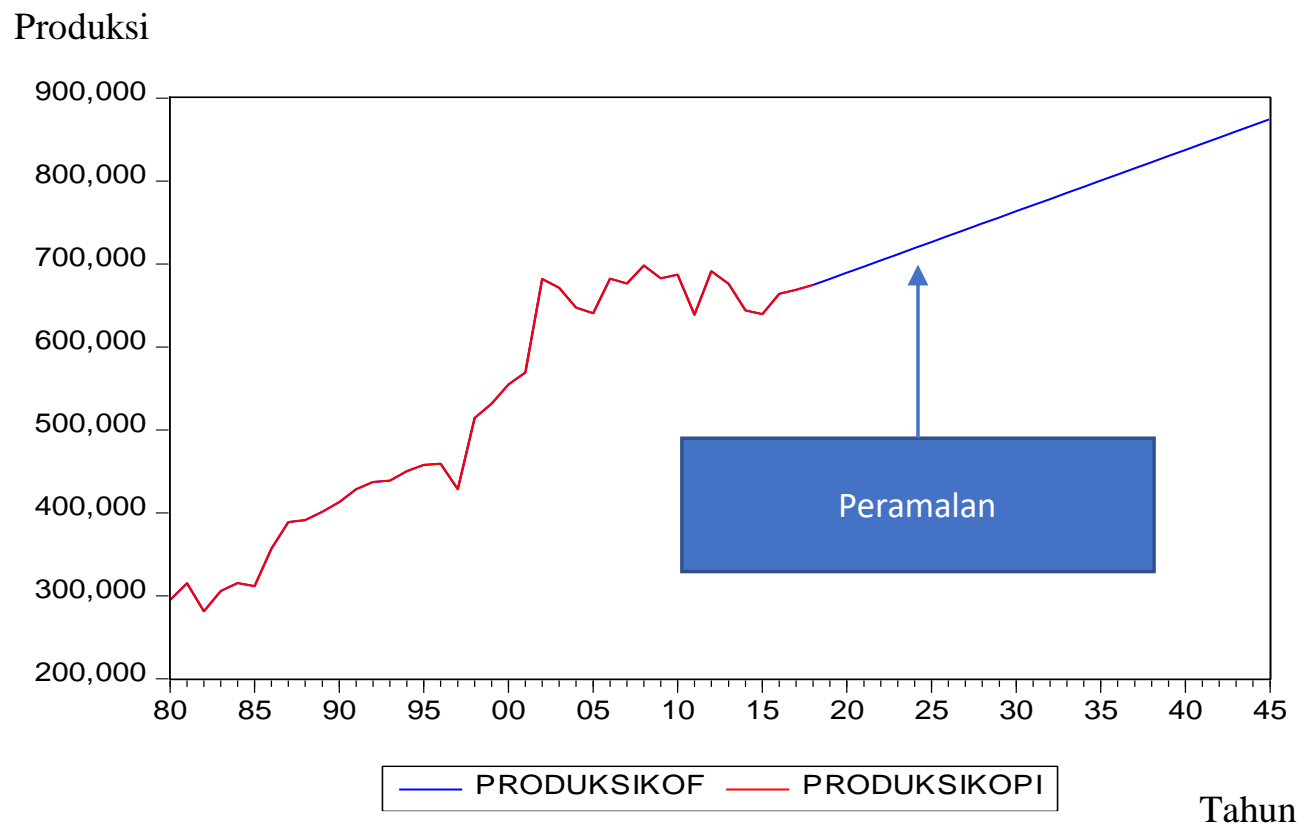

Gambar 4. Peramalan Produksi Kopi Periode Tahun 2019-2045

Hasil peramalan berdasarkan skenario moderat dan optimis pada derajat kepercayaan 95 persen menunjukkan bahwa produksi kopi di Indonesia pada tahun 2045 cenderung meningkat yaitu 874.508 ton dan 1.659 .883 ton. Sementara itu, berdasarkan skenario pesimis justru terus mengalami penurunan, yaitu pada tahun 2045 sebesar 89.132 ton. Lebih jelasnya dapat dilihat pada Tabel 4 dibawah ini.

Tabel 4. Peramalan Produksi Kopi Tahun 2019-2045 dengan Skenario Pesimis, Moderat dan Optimis (ton)

\begin{tabular}{|c|c|c|c|}
\hline Tahun & $\begin{array}{c}\text { Peramalan Produksi } \\
\text { Skenario Pesimis }\end{array}$ & $\begin{array}{c}\text { Peramalan Produksi } \\
\text { Skenario Moderat }\end{array}$ & $\begin{array}{c}\text { Peramalan Produksi } \\
\text { Skenario Optimis }\end{array}$ \\
\hline 2019 & 607.772 & 682.039 & 756.305 \\
\hline 2020 & 578.892 & 689.441 & 799.991 \\
\hline 2021 & 554.583 & 696.844 & 839.104 \\
\hline 2022 & 548.054 & 704.247 & 860.439 \\
\hline 2023 & 540.475 & 711.649 & 882.823 \\
\hline 2024 & 532.153 & 719.052 & 905.950 \\
\hline 2025 & 517.375 & 726.455 & 935.535 \\
\hline 2026 & 502.138 & 733.857 & 965.577 \\
\hline 2027 & 486.268 & 741.260 & 1025.254 \\
\hline 2028 & 472.071 & 748.663 & 1055.113 \\
\hline 2029 & 457.018 & 756.065 & 1085.773 \\
\hline 2030 & 441.163 & 763.468 & 1.118 .168 \\
\hline 2031 & 423.573 & 770.870 & 1.151 .353 \\
\hline 2032 & 405.194 & 778.273 & 1.185 .374 \\
\hline 2033 & 385.978 & 785.676 & 1.219 .877 \\
\hline 2034 & 366.280 & 793.078 & 1.255 .264 \\
\hline 2035 & 345.698 & 800.481 & 1.291 .532 \\
\hline 2036 & 324.235 & 807.884 & 1.328 .839 \\
\hline 2037 & 301.734 & 815.286 & 1.367 .037 \\
\hline 2038 & 278.341 & 822.689 & 1.406 .141 \\
\hline 2039 & 254.042 & 830.092 & 1.446 .099 \\
\hline 2040 & 228.889 & 837.494 & 1.486 .980 \\
\hline 2041 & 202.814 & 844.897 & \\
\hline & & & \\
\hline
\end{tabular}


Bayu Kharisma. Peramalan Indikator Mikro Kinerja Komoditas Strategis......

\begin{tabular}{|l|c|c|c|}
\hline 2042 & 175.812 & 852.300 & 1.528 .787 \\
\hline 2043 & 147.856 & 859.702 & 1.571 .549 \\
\hline 2044 & 118.964 & 867.105 & 1.615 .246 \\
\hline 2045 & 89.132 & 874.508 & 1.659 .883 \\
\hline
\end{tabular}

Sumber : Hasil Perhitungan ARIMAX $(0,2,1)$

\section{Sisi Luas Areal}

Sistem pengusahaan kopi di Indonesia pada periode tahun 1980-2018 sebagian besar merupakan perkebunan yang diusahakan oleh rakyat. Hal ini dapat dilihat pada data Direktorat Jenderal Perkebunan, bahwa luas areal untuk kopi PR (Perkebunan Rakyat) mencapai rata-rata $95 \%$ dari total luas areal menurut status pengusahaan. Sejalan dengan pola perkembangan produksi kopi Indonesia, luas areal kopi juga mengalami kecenderungan peningkatan luas lahan pada periode 1980-2018. Apabila pada tahun 1980 luas areal kopi Indonesia hanya mencapai 707.464 ha maka pada tahun 2018, luas areal kopi Indonesia meningkat menjadi 1.259 .136 ha atau meningkat sebesar 56,19\%. Peningkatan luas areal selama tahun 1980-2018, sejalan dengan hasil peramalan selama tahun 2019 sampai tahun 2045, dimana luas areal kopi pada tahun 2045 mengalami peningkatan yaitu 1.711.896 Ha.

Luas areal (Ha)

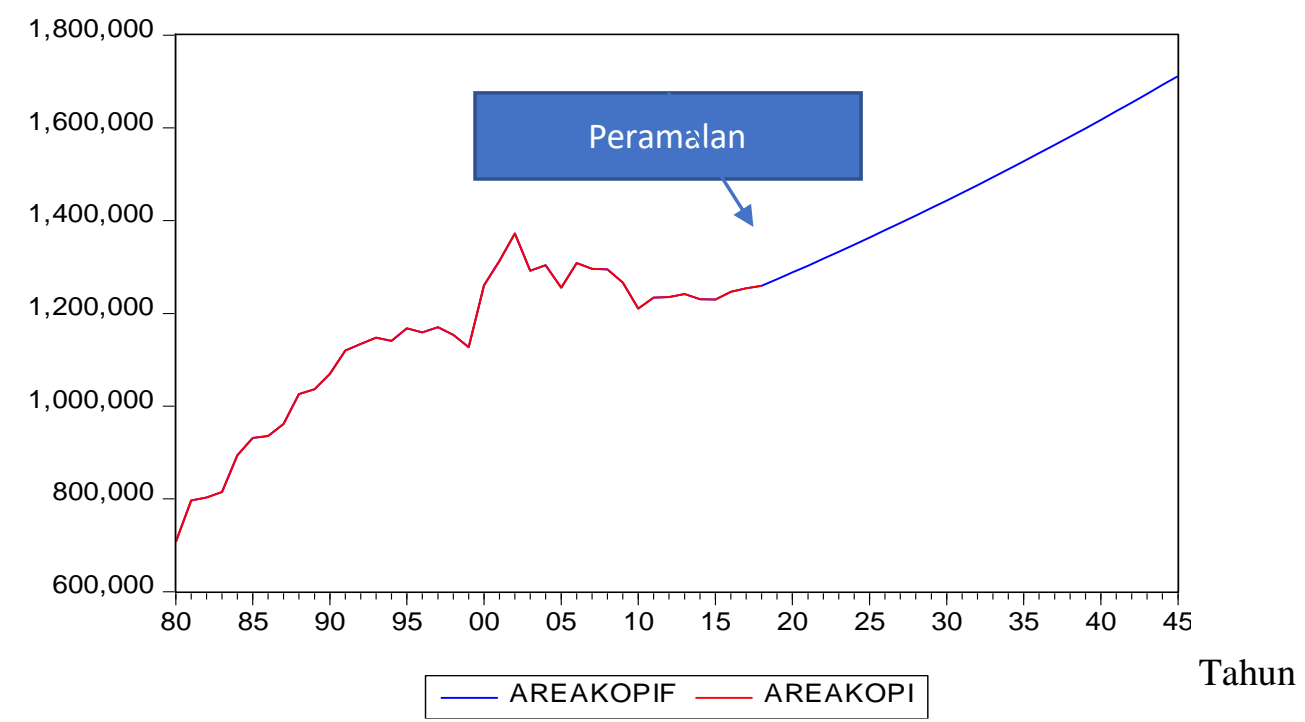

\section{Gambar 5. Peramalan Luas Areal Kopi Periode Tahun 2019-2045}

Adanya peningkatan luas areal lahan ke depan tidak lepas adanya peningkatan dari aspek budidaya, aspek pengolahan, serta aspek peningkatan pasar sekaligus konsumsi per kapita per tahunnya. Sebagai kasus, di Provinsi Jawa Barat adanya bantuan benih pohon kopi ini, akan semakin menambah luas lahan perkebunan kopi di Jawa Barat serta didukung oleh sebagian besar para petani kopi telah mampu melakukan pengolahan. Selain itu, tingginya areal perhutani yang dijadikan untuk komoditas kopi (contoh kasus di Bondowoso). Hasil peramalan berdasarkan skenario moderat dan optimis pada derajat kepercayaan 95 persen menunjukkan bahwa luas areal kopi di Indonesia pada tahun 2045 cenderung meningkat yaitu 1.711.896 Ha dan 2.469.666 Ha. Sementara itu, berdasarkan skenario pesimis luas areal kopi terus mengalami penurunan, yaitu pada tahun 2045 sebesar 954.126 Ha. Lebih jelasnya dapat dilihat pada Tabel 5 dibawah ini. 
E-Jurnal Ekonomi dan Bisnis Universitas Udayana 8.3 (2019): 235-258

Tabel 5. Peramalan Luas Areal Kopi Tahun 2019-2045 dengan Skenario Pesimis, Moderat dan Optimis (Ha)

\begin{tabular}{|c|c|c|c|}
\hline Tahun & $\begin{array}{l}\text { Peramalan Produksi } \\
\text { Skenario Pesimis }\end{array}$ & $\begin{array}{c}\text { Peramalan Produksi } \\
\text { Skenario Moderat }\end{array}$ & $\begin{array}{l}\text { Peramalan Produksi } \\
\text { Skenario Optimis }\end{array}$ \\
\hline 2019 & 1.186 .765 & 1.273 .543 & 1.360 .320 \\
\hline 2020 & 1.162 .776 & 1.288 .115 & 1.413 .453 \\
\hline 2021 & 1.146 .090 & 1.302 .853 & 1.459 .616 \\
\hline 2022 & 1.132 .926 & 1.317 .760 & 1.502 .594 \\
\hline 2023 & 1.121 .848 & 1.332 .838 & 1.543 .827 \\
\hline 2024 & 1.112 .131 & 1.348 .088 & 1.584 .045 \\
\hline 2025 & 1.103 .349 & 1.363 .512 & 1.623 .675 \\
\hline 2026 & 1.095 .231 & 1.379 .113 & 1.662 .996 \\
\hline 2027 & 1087.586 & 1.394 .893 & 1.702 .200 \\
\hline 2028 & 1080.279 & 1.410 .853 & 1.741 .427 \\
\hline 2029 & 1073.207 & 1.426 .996 & 1.780 .785 \\
\hline 2030 & 1066.290 & 1.443 .323 & 1.820 .357 \\
\hline 2031 & 1059.464 & 1.459 .838 & 1.860 .211 \\
\hline 2032 & 1052.678 & 1.476 .541 & 1.900 .404 \\
\hline 2033 & 1045.887 & 1.493 .435 & 1.940 .983 \\
\hline 2034 & 1039.056 & 1.510 .523 & 1.981 .990 \\
\hline 2035 & 1032.151 & 1.527 .806 & 2.023 .461 \\
\hline 2036 & 1025.146 & 1.545 .287 & 2.065 .428 \\
\hline 2037 & 1018.015 & 1.562 .968 & 2.107 .921 \\
\hline 2038 & 1010.736 & 1.580 .851 & 2.150 .966 \\
\hline 2039 & 1003.289 & 1.598 .939 & 2.194 .589 \\
\hline 2040 & 995.656 & 1.617 .234 & 2.238 .812 \\
\hline 2041 & 987.818 & 1.635 .738 & 2.283 .657 \\
\hline 2042 & 979.762 & 1.654 .454 & 2.329 .145 \\
\hline 2043 & 971.470 & 1.673 .384 & 2.375 .297 \\
\hline 2044 & 962.929 & 1.692 .530 & 2.422 .131 \\
\hline 2045 & 954.126 & 1.711 .896 & 2.469 .666 \\
\hline
\end{tabular}

Sumber : Hasil Perhitungan ARIMAX $(3,2,1)$

\section{Sisi Produktivitas}

Sama halnya dengan pola produksi dan luas areal kopi yang terus mengalami peningkatan, sejalan dengan tingkat produktivitas kopi yang terus naik. Hal ini dapat dilihat dari Gambar 6 dibawah ini. 


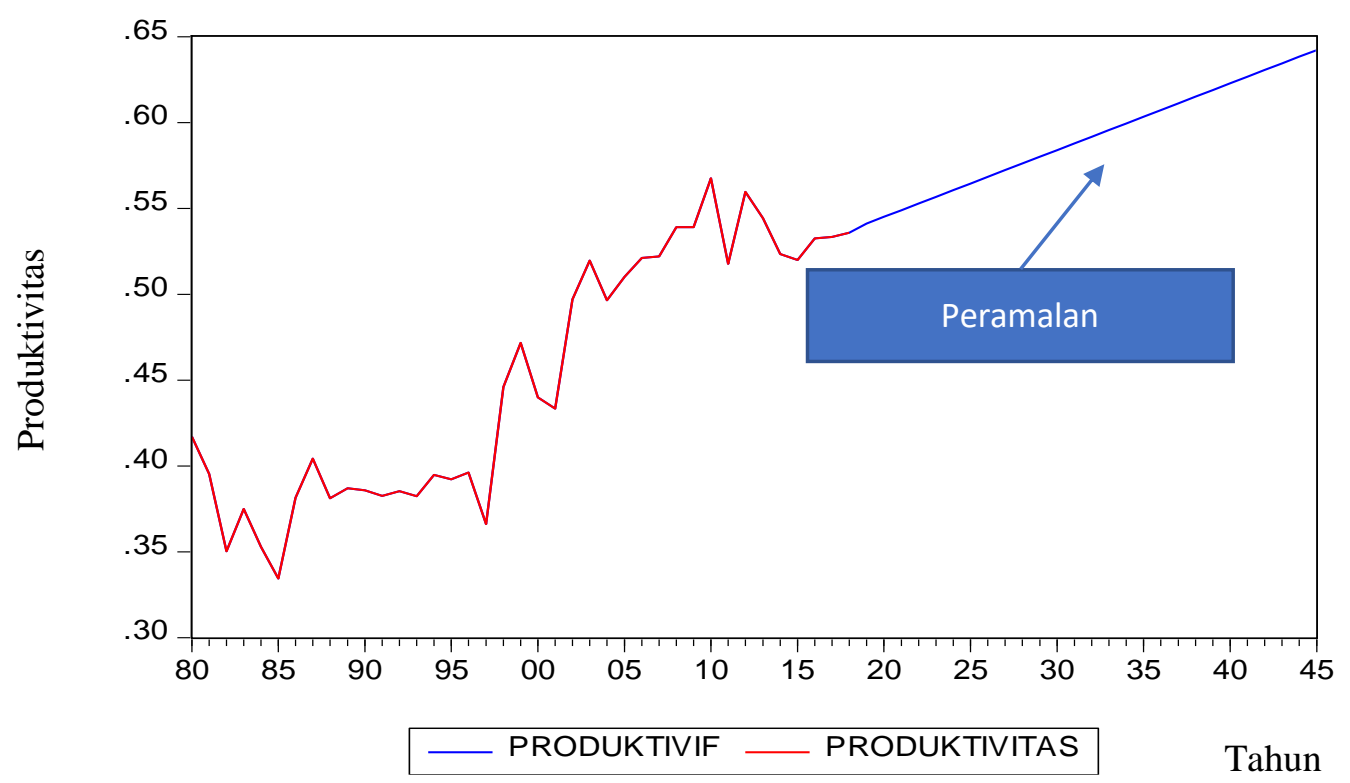

\section{Gambar 6. Peramalan Produktivitas Kopi Periode Tahun 2019-2045}

Adanya peningkatan produktivitas kopi tersebut antara lain disebabkan oleh replanting terhadap hektare lahan kopi. Selain itu, adanya kebijakan yang dilakukan oleh kementerian pertanian dalam upaya peningkatan produktivitas melalui perbaikan mutu tanaman, penerapan Good Agriculture Practices (GAP), pengendalian organisme pengganggu tanaman (OPT) dan penyediaan benih unggul bermutu serta sarana produksi.

Apabila dilihat dari peramalan berdasarkan skenario moderat pada derajat kepercayaan 95 persen menunjukkan bahwa produktivitas kopi di Indonesia pada tahun 2019-2045 cenderung meningkat, yaitu 0,54 pada tahun 2019 dan tahun 2045 menjadi 0,64 atau naik sebesar $15,73 \%$. Sama halnya dengan skenario optimis, tingkat produktivitas kopi selama tahun 2019-2045 naik mencapai 29,30\%, sedangkan berdasarkan skenario pesimis nilai produktivitas kopi terus mengalami penurunan, yaitu 0,44 pada tahun 2045. Lebih jelasnya dapat dilihat dari Tabel 6 dibawah ini.

Tabel 6. Peramalan Produktivitas Kopi Tahun 2019-2045 dengan Skenario Pesimis, Moderat dan Optimis (ton per hektare)

\begin{tabular}{|c|c|c|c|}
\hline Tahun & $\begin{array}{c}\text { Peramalan } \\
\text { Produktivitas } \\
\text { Skenario Pesimis }\end{array}$ & $\begin{array}{c}\text { Peramalan Produktivitas } \\
\text { Skenario Moderat }\end{array}$ & $\begin{array}{c}\text { Peramalan Produktivitas } \\
\text { Skenario Optimis }\end{array}$ \\
\hline 2019 & 0.4882 & 0.5412 & 0.5941 \\
\hline 2020 & 0.4844 & 0.5450 & 0.6057 \\
\hline 2021 & 0.4812 & 0.5489 & 0.6166 \\
\hline 2022 & 0.4784 & 0.5528 & 0.6272 \\
\hline 2023 & 0.4759 & 0.5567 & 0.6375 \\
\hline 2024 & 0.4735 & 0.5606 & 0.6476 \\
\hline 2025 & 0.4714 & 0.5645 & 0.6575 \\
\hline 2026 & 0.4695 & 0.5684 & 0.6673 \\
\hline 2027 & 0.4676 & 0.5722 & 0.6769 \\
\hline 2028 & 0.4659 & 0.5761 & 0.6864 \\
\hline 2029 & 0.4642 & 0.5800 & 0.6958 \\
\hline 2030 & 0.4626 & 0.5839 & 0.7052 \\
\hline 2031 & 0.4611 & 0.5878 & 0.7145 \\
\hline 2032 & 0.4597 & 0.5917 & 0.7237 \\
\hline 2033 & 0.4583 & 0.5956 & 0.7328 \\
\hline 2034 & 0.4569 & 0.5995 & 0.7420 \\
\hline
\end{tabular}


E-Jurnal Ekonomi dan Bisnis Universitas Udayana 8.3 (2019): 235-258

\begin{tabular}{|l|l|l|l|}
\hline 2035 & 0.4556 & 0.6033 & 0.7511 \\
\hline 2036 & 0.4544 & 0.6072 & 0.7601 \\
\hline 2037 & 0.4531 & 0.6111 & 0.7691 \\
\hline 2038 & 0.4519 & 0.6150 & 0.7781 \\
\hline 2039 & 0.4507 & 0.6189 & 0.7870 \\
\hline 2040 & 0.4496 & 0.6228 & 0.7960 \\
\hline 2041 & 0.4485 & 0.6267 & 0.8049 \\
\hline 2042 & 0.4474 & 0.6306 & 0.8138 \\
\hline 2043 & 0.4463 & 0.6344 & 0.8226 \\
\hline 2044 & 0.4452 & 0.6383 & 0.8315 \\
\hline 2045 & 0.4441 & 0.6422 & 0.8403 \\
\hline
\end{tabular}

Sumber : Hasil Perhitungan ARIMAX $(0,2,1)$

\section{c. Komoditas Tebu}

\section{Sisi Produksi}

Selama periode tahun 1967-2018 produksi tebu Indonesia cenderung terus mengalami peningkatan, yaitu dari 833. 900 ton pada tahun 1980 menjadi 2.200.000 ton pada tahun 2018, dimana peningkatan produksi kopi tertinggi pada periode tersebut terjadi pada tahun 2008 sebesar 2.694.227 ton, sedangkan produksi tebu di Indonesia mengalami penurunan cukup signifikan pada saat Indonesia terkena krisis ekonomi di tahun 1998 yang mencapai 1.488 .269 ton

Sementara itu, hasil peramalan selama tahun 2019 sampai tahun 2045 produksi gula kemudian cenderung terus meningkat, meskipun mengalami fluktuatif. Adanya fluktuasi tersebut antara lain tidak lepas karena masalah iklim, misalnya kemarau basah sehingga terjadi turunnya rendemen karena tebu yang dipanen bercampur dengan air. Secara lengkap, perkembangan produksi tebu menurut status pengusahaan selama periode 19672045 dapat dilihat pada Gambar 7 berikut ini.

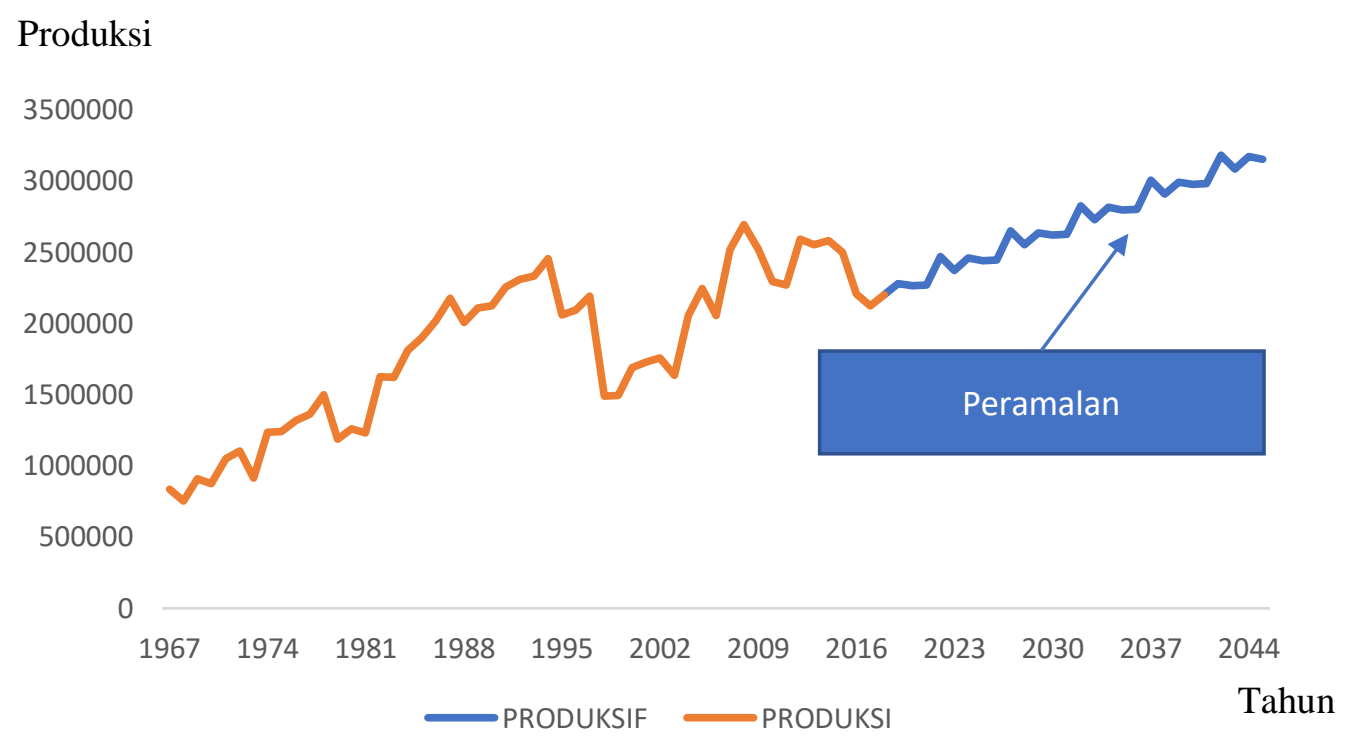

\section{Gambar 7. Peramalan Produksi Tebu Periode Tahun 2019-2045}

Hasil peramalan berdasarkan skenario moderat pada derajat kepercayaan 95 persen menunjukkan bahwa produksi tebu di Indonesia pada tahun 2019-2045 cenderung meningkat, meskipun berfluktuatif yaitu 2.279.484 ton pada tahun 2019 dan tahun 2045 menjadi 3.152.320 ton. Sama halnya dengan skenario optimis, dimana tingkat produksi tebu selama tahun 2019-2045 naik, sedangkan berdasarkan skenario pesimis produksi tebu 
mengalami penurunan, yaitu 1.852.194 ton pada tahun 2019 menjadi 371.070 ton pada tahun 2025. Lebih jelasnya dapat dilihat dari Tabel 7 dibawah ini.

Tabel 7. Peramalan Produksi Tebu Tahun 2019-2045 dengan Skenario Pesimis, Moderat dan Optimis (ton)

\begin{tabular}{|c|c|c|c|}
\hline Tahun & $\begin{array}{c}\begin{array}{c}\text { Peramalan Produksi } \\
\text { (ton) }\end{array} \\
\text { Skenario Pesimis }\end{array}$ & $\begin{array}{c}\text { Peramalan Produksi } \\
\text { (ton) } \\
\text { Skenario Moderat }\end{array}$ & $\begin{array}{c}\text { Peramalan Produksi } \\
\text { (ton) } \\
\text { Skenario Optimis }\end{array}$ \\
\hline 2019 & 1.852 .194 & 2.279 .484 & 2.706 .774 \\
\hline 2020 & 1.642 .436 & 2.262 .328 & 2.882 .220 \\
\hline 2021 & 1.488 .035 & 2.265 .947 & 3.043 .859 \\
\hline 2022 & 1.549 .779 & 2.469 .179 & 3.388 .579 \\
\hline 2023 & 1.320 .322 & 2.371 .416 & 3.422 .510 \\
\hline 2024 & 1.281 .162 & 2.457 .482 & 3.633 .802 \\
\hline 2025 & 1.143 .342 & 2.440 .326 & 3.737 .310 \\
\hline 2026 & 1.029 .663 & 2.443 .945 & 3.858 .227 \\
\hline 2027 & 1.118 .164 & 2.647 .178 & 4.176 .192 \\
\hline 2028 & 927.672 & 2.549 .414 & 4.171 .156 \\
\hline 2029 & 882.605 & 2.635 .481 & 4.388 .357 \\
\hline 2030 & 955.603 & 2.618 .325 & 4.281 .047 \\
\hline 2031 & 650.428 & 2.621 .944 & 4.593 .460 \\
\hline 2032 & 745.734 & 2.825 .176 & 4.904 .618 \\
\hline 2033 & 700.767 & 2.727 .413 & 4.754 .059 \\
\hline 2034 & 520.233 & 2.813 .479 & 5.106 .725 \\
\hline 2035 & 576.983 & 2.796 .323 & 5.015 .663 \\
\hline 2036 & 294.934 & 2.799 .942 & 5.304 .950 \\
\hline 2037 & 392.857 & 3.003 .175 & 5.613 .493 \\
\hline 2038 & 310.087 & 2.905 .411 & 5.500 .735 \\
\hline 2039 & 171.404 & 2.991 .478 & 5.811 .552 \\
\hline 2040 & 169.712 & 2.974 .322 & 5.778 .932 \\
\hline 2041 & 174.975 & 2.977 .941 & 5.780 .907 \\
\hline 2042 & 247.997 & 3.181 .173 & 6.114 .349 \\
\hline 2043 & 246.148 & 3.083 .410 & 5.920 .672 \\
\hline 2044 & 388.226 & 3.169 .476 & 5.950 .726 \\
\hline 2045 & 371.070 & 3.152 .320 & 5.933 .570 \\
\hline
\end{tabular}

Sumber : Hasil Perhitungan ARIMAX $(0,2,1)$

\section{Sisi Luas Areal}

Sama halnya dengan pola produksi dan luas areal tebu mengalami peningkatan. Secara umum, luas panen tebu di Indonesia mengalami peningkatan sejak tahun 1967 sampai 2018 (Gambar 7). Pada tahun 1967, luas panen tebu di Indonesia hanya seluas 103.773 ha. Luas ini kemudian meningkat sebesar 76,63\% menjadi 444.021 ha pada tahun 2018 dan diperkirakan akan kembali meningkat menjadi sebesar 640.712 ha di tahun 2045, meskipun berfluktuasi karena sangat dipengaruhi oleh pendapatan petani dan iklim.

Peningkatan luas panen ini lebih disebabkan oleh adanya peningkatan pada luas panen tebu di Perkebunan Rakyat. Hal ini dikarenakan sebagian besar perkebunan tebu di Indonesia diusahakan oleh petani tebu rakyat dibandingkan kontribusi dari perkebunan tebu milik perusahaan (PBN atau PBS). 


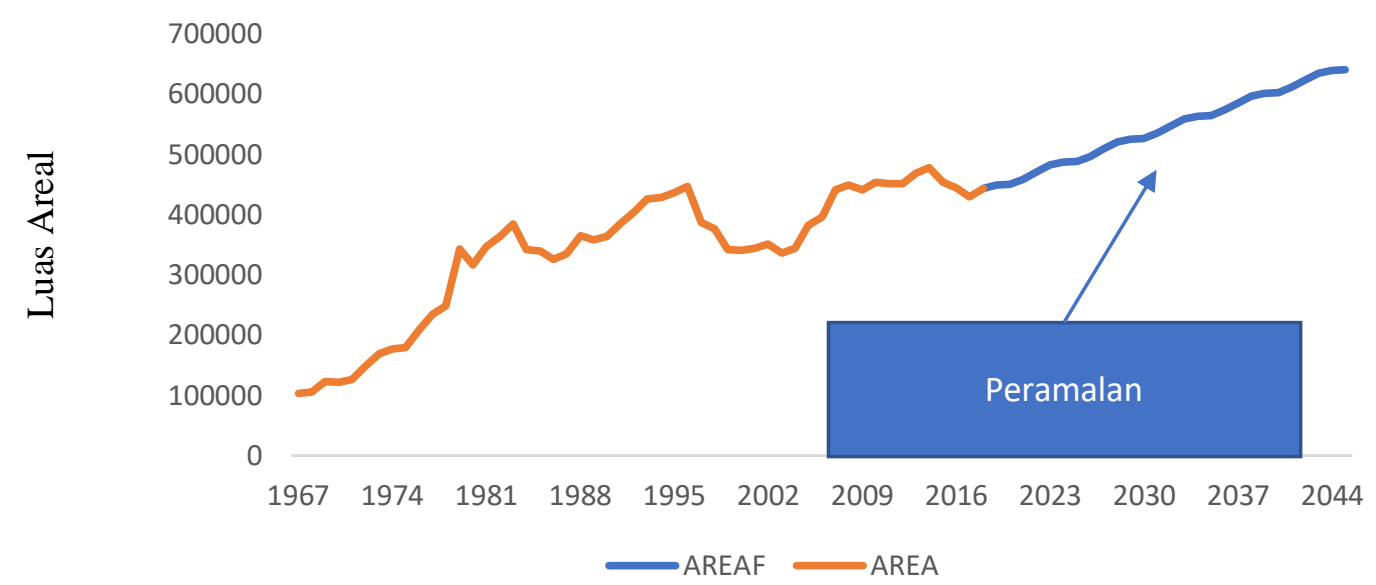

Tahun

\section{Gambar 8. Peramalan Luas Areal Tebu Periode Tahun 2019-2045}

Sementara itu, hasil peramalan skenario moderat dan optimis pada derajat kepercayaan 95 persen menunjukkan bahwa luas areal tebu di Indonesia pada tahun 2045 cenderung meningkat yaitu $640.712 \mathrm{Ha}$ dan 1.086.170 Ha. Sementara itu, berdasarkan skenario pesimis justru terus mengalami penurunan, yaitu pada tahun 2045 sebesar 195.254 Ha. Lebih jelasnya dapat dilihat pada Tabel 8 dibawah ini.

Tabel 8. Peramalan Luas Areal Tebu Tahun 2019-2045 dengan Skenario Pesimis, Moderat dan Optimis (Hektare)

\begin{tabular}{|c|c|c|c|}
\hline Tahun & $\begin{array}{l}\text { Peramalan Produksi } \\
\text { Skenario Pesimis }\end{array}$ & $\begin{array}{l}\text { Peramalan Produksi } \\
\text { Skenario Moderat }\end{array}$ & $\begin{array}{l}\text { Peramalan Produksi } \\
\text { Skenario Optimis }\end{array}$ \\
\hline 2019 & 399.877 & 448.915 & 497.953 \\
\hline 2020 & 378.040 & 449.936 & 521.832 \\
\hline 2021 & 367.727 & 458.807 & 549.887 \\
\hline 2022 & 362.626 & 471.192 & 579.758 \\
\hline 2023 & 357.097 & 482.176 & 607.255 \\
\hline 2024 & 346.100 & 487.070 & 628.040 \\
\hline 2025 & 331.655 & 488.092 & 644.529 \\
\hline 2026 & 325.361 & 496.962 & 668.563 \\
\hline 2027 & 322.804 & 509.347 & 695.890 \\
\hline 2028 & 319.012 & 520.331 & 721.650 \\
\hline 2029 & 309.256 & 525.225 & 741.194 \\
\hline 2030 & 295.726 & 526.247 & 756.768 \\
\hline 2031 & 290.119 & 535.118 & 780.117 \\
\hline 2032 & 288.082 & 547.502 & 806.922 \\
\hline 2033 & 284.691 & 558.487 & 832.283 \\
\hline 2034 & 275.241 & 563.381 & 851.521 \\
\hline 2035 & 261.942 & 564.402 & 866.862 \\
\hline 2036 & 256.510 & 573.273 & 890.036 \\
\hline 2037 & 254.602 & 585.657 & 916.712 \\
\hline 2038 & 251.301 & 596.642 & 941.983 \\
\hline 2039 & 241.911 & 601.536 & 961.161 \\
\hline 2040 & 228.646 & 602.557 & 976.468 \\
\hline 2041 & 223.226 & 611.428 & 999.630 \\
\hline 2042 & 221.312 & 623.812 & 1.026 .312 \\
\hline 2043 & 217.990 & 634.797 & 1.051 .604 \\
\hline 2044 & 208.565 & 639.691 & 1.070 .817 \\
\hline 2045 & 195.254 & 640.712 & 1.086 .170 \\
\hline
\end{tabular}

Sumber : Hasil Perhitungan ARIMAX $(0,2,1)$ 


\section{Sisi Produktivitas}

Sama halnya dengan pola produksi dan luas areal yang terus mengalami peningkatan selama periode 2019-2045, kondisi ini sejalan dengan tingkat produktivitas tebu yang naik, meskipun cenderung lambat. Lambanya kenaikan produktivitas tersebut diduga karena adanya faktor iklim dan teknik budidaya. Secara umum, rata-rata produktivitas tebu di Indonesia pada periode tahun 2019-2045 diperamalan mencapai 5,02 Ha. Hal ini dapat dilihat dari Gambar 9 dibawah ini.

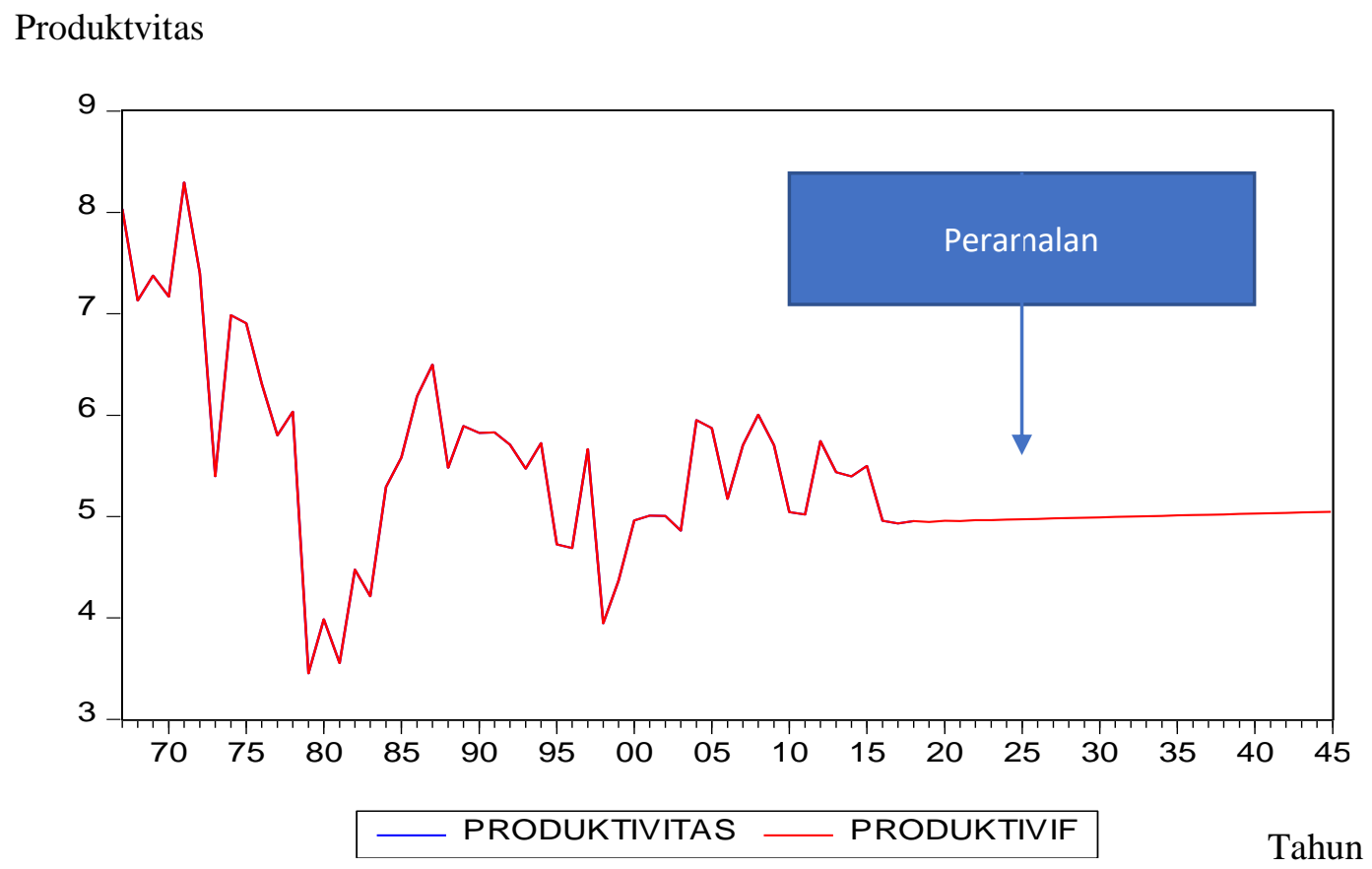

Gambar 9. Peramalan Produktivitas Tebu Periode Tahun 2019-2045

Sementara itu, hasil peramalan skenario moderat dan optimis pada derajat kepercayaan 95 persen menunjukkan bahwa produktivitas tebu di Indonesia pada tahun 2045 cenderung meningkat yaitu 5.0742 dan 9.8692. Sementara itu, berdasarkan skenario pesimis justru terus mengalami penurunan, yaitu pada tahun 2045 sebesar 0.2791. Lebih jelasnya dapat dilihat pada Tabel 9 dibawah ini.

Tabel 9. Peramalan Produktivitas Tebu Tahun 2019-2045 dengan Skenario Pesimis, Moderat dan Optimis

\begin{tabular}{|c|c|c|c|}
\hline Tahun & $\begin{array}{c}\text { Peramalan Produksi } \\
\text { Skenario Pesimis }\end{array}$ & $\begin{array}{c}\text { Peramalan Produksi } \\
\text { Skenario Moderat }\end{array}$ & $\begin{array}{c}\text { Peramalan Produksi } \\
\text { Skenario Optimis }\end{array}$ \\
\hline 2019 & 3.3892 & 4.9591 & 6.5291 \\
\hline 2020 & 2.7171 & 4.9636 & 7.2100 \\
\hline 2021 & 2.1850 & 4.9680 & 7.7510 \\
\hline 2022 & 1.7227 & 4.9724 & 8.2221 \\
\hline 2023 & 1.3035 & 4.9768 & 8.6502 \\
\hline 2024 & 0.9140 & 4.9813 & 9.0485 \\
\hline 2025 & 0.5462 & 4.9857 & 9.4252 \\
\hline
\end{tabular}


ISSN : 2337-3067

E-Jurnal Ekonomi dan Bisnis Universitas Udayana 8.3 (2019): 235-258

\begin{tabular}{|l|l|l|l|}
\hline 2026 & 0.1950 & 4.9901 & 9.7852 \\
\hline 2027 & 0.1995 & 4.9945 & 9.7896 \\
\hline 2028 & 0.2039 & 4.9990 & 9.7940 \\
\hline 2029 & 0.2083 & 5.0034 & 9.7985 \\
\hline 2030 & 0.2127 & 5.0078 & 9.8029 \\
\hline 2031 & 0.2172 & 5.0122 & 9.8073 \\
\hline 2032 & 0.2216 & 5.0167 & 9.8117 \\
\hline 2033 & 0.2260 & 5.0211 & 9.8161 \\
\hline 2034 & 0.2304 & 5.0255 & 9.8206 \\
\hline 2035 & 0.2349 & 5.0299 & 9.8250 \\
\hline 2036 & 0.2393 & 5.0344 & 9.8294 \\
\hline 2037 & 0.2437 & 5.0388 & 9.8338 \\
\hline 2038 & 0.2481 & 5.0432 & 9.8383 \\
\hline 2039 & 0.2526 & 5.0476 & 9.8427 \\
\hline 2040 & 0.2570 & 5.0520 & 9.8515 \\
\hline 2041 & 0.2614 & 5.0565 & 9.8560 \\
\hline 2042 & 0.2658 & 5.0609 & 9.8604 \\
\hline 2043 & 0.2702 & 5.0653 & 9.8648 \\
\hline 2044 & 0.2747 & 5.0697 & 9.8692 \\
\hline 2045 & 0.2791 & 5.0742 & \\
\hline
\end{tabular}

Sumber : Hasil Perhitungan ARIMAX $(1,2,0)$

\section{d. Komoditas Kakao}

\section{Sisi Produksi}

Apabila ditinjau dari produksinya selama kurun waktu 1967-2018, produksi kakao Indonesia berfluktuasi dan cenderung meningkat. Pada tahun 1967, tingkat produksi kakao mencapai 1233 ton, sementara pada tahun 2018 mencapai 686.964 ton. Terjadinya fluktuasi produksi kakao tersebut antara lain disebabkan karena harga biji kakao di pasar internasional sangat berfluktuasi. Kondisi yang sama untuk peramalan tahun 2019-2045, dimana produksi kakao Indonesia cenderung naik. Perkembangan produksi kakao di Indonesia secara rinci dapat dilihat pada Gambar 10.

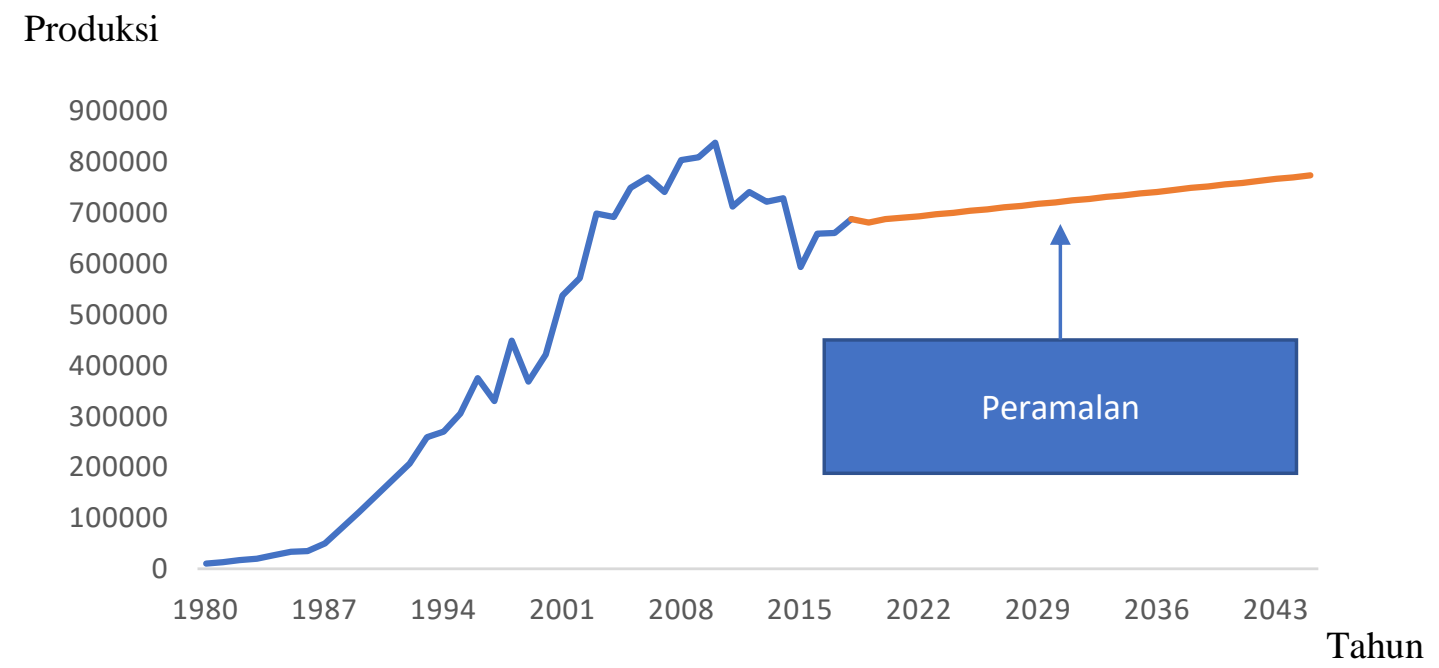

\section{Gambar 10. Peramalan Produksi Kakao Periode Tahun 2019-2045}

Sementara itu, hasil peramalan skenario moderat dan optimis pada derajat kepercayaan 95 persen menunjukkan bahwa produksi kakao di Indonesia pada tahun 2045 cenderung meningkat yaitu 773.483 ton dan 5.738.498. Sementara itu, berdasarkan 
skenario pesimis terus mengalami penurunan, yaitu pada tahun 2045 sebesar 90.121. Lebih jelasnya dapat dilihat pada Tabel 10 dibawah ini.

Tabel 10. Peramalan Produksi Kakao Tahun 2019-2045 dengan Skenario Pesimis, Moderat dan Optimis

\begin{tabular}{|c|c|c|c|}
\hline Tahun & $\begin{array}{l}\text { Peramalan Produksi } \\
\text { Skenario Pesimis }\end{array}$ & $\begin{array}{l}\text { Peramalan Produksi } \\
\text { Skenario Moderat }\end{array}$ & $\begin{array}{l}\text { Peramalan Produksi } \\
\text { Skenario Optimis }\end{array}$ \\
\hline 2019 & 497,429 & 680,992 & 864,555 \\
\hline 2020 & 428,242 & 687,741 & 947,240 \\
\hline 2021 & 329,154 & 689,685 & $1,050,216$ \\
\hline 2022 & 228,218 & 693,480 & $1,158,742$ \\
\hline 2023 & 116,402 & 696,593 & $1,276,783$ \\
\hline 2024 & 111,200 & 699,987 & $1,402,986$ \\
\hline 2025 & 101,202 & 703,296 & $1,537,342$ \\
\hline 2026 & 111,119 & 706,659 & $1,679,592$ \\
\hline 2027 & 110,001 & 710,024 & $1,829,540$ \\
\hline 2028 & 101,161 & 713,410 & $1,987,033$ \\
\hline 2029 & 101,900 & 716,810 & $2,151,926$ \\
\hline 2030 & 100,086 & 720,228 & $2,324,104$ \\
\hline 2031 & 100,001 & 723,661 & $2,503,466$ \\
\hline 2032 & 99,199 & 727,111 & $2,689,925$ \\
\hline 2033 & 98,481 & 730,577 & $2,883,409$ \\
\hline 2034 & 97,320 & 734,060 & $3,083,856$ \\
\hline 2035 & 96,320 & 737,559 & $3,291,214$ \\
\hline 2036 & 95,121 & 741,075 & $3,505,439$ \\
\hline 2037 & 94,991 & 744,608 & $3,726,496$ \\
\hline 2038 & 94,311 & 748,157 & $3,954,354$ \\
\hline 2039 & 93,902 & 751,724 & $4,188,992$ \\
\hline 2040 & 92,181 & 755,307 & $4,430,391$ \\
\hline 2041 & 92,999 & 758,908 & $4,678,538$ \\
\hline 2042 & 92,222 & 762,526 & $4,933,425$ \\
\hline 2043 & 91,897 & 766,161 & $5,195,048$ \\
\hline 2044 & 90,990 & 769,813 & $5,463,404$ \\
\hline 2045 & 90,121 & 773,483 & $5,738,498$ \\
\hline
\end{tabular}

Sumber : Hasil Perhitungan ARIMAX $(0,2,1)$

\section{Sisi Luas Areal}

Pada periode tahun 1967-2018 secara umum pola perkembangan luas areal kakao di Indonesia cenderung meningkat. Kondisi yang sama terjadi dengan tahun 2019-2045, dimana luas areal kakao cenderung terus meningkat.

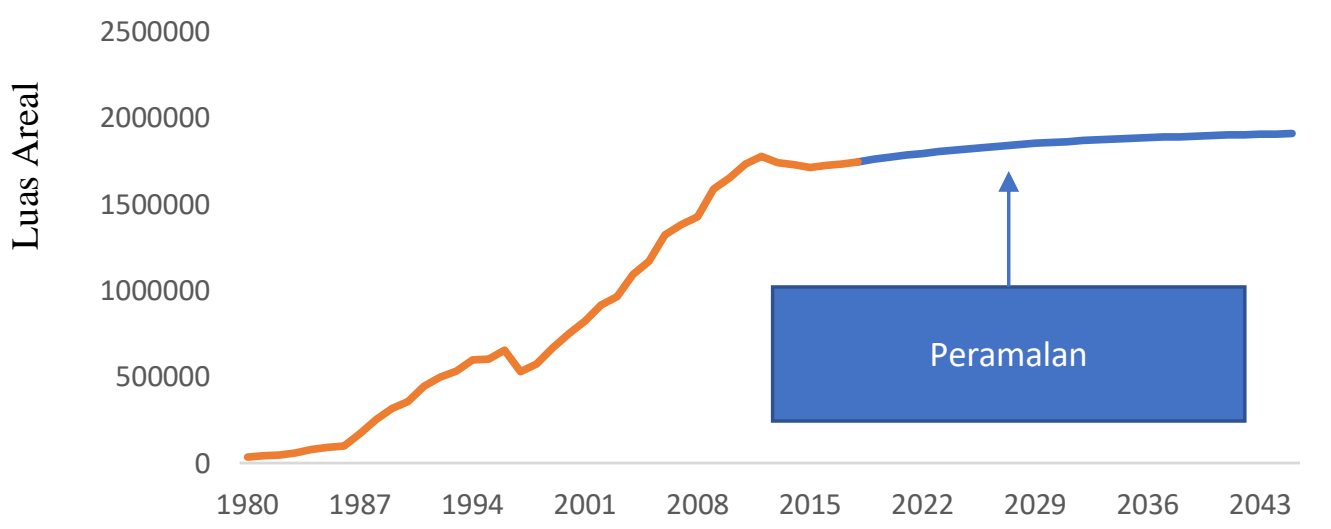

Tahun

Gambar 11. Peramalan Luas Areal Kakao Periode Tahun 2019-2045 
Sementara itu, hasil peramalan skenario moderat pada derajat kepercayaan 95 persen menunjukkan bahwa luas areal kakao di Indonesia pada tahun 2045 sebesar 1,906,109 Ha atau naik sebesar 7.79\% dibandingkan 2019. Hal yang sama pada skenario optimis bahwa luas areal kakao di Indonesia pada tahun 2045 terus meningkat, sedangkan hasil skenario pesimis menunjukkan hasil yang sebaliknya. Lebih jelasnya dapat dilihat pada Tabel 11 dibawah ini.

Tabel 11. Peramalan Luas Areal Kakao Tahun 2019-2045 dengan Skenario Pesimis, Moderat dan Optimis

\begin{tabular}{|c|c|c|c|}
\hline Tahun & $\begin{array}{c}\text { Peramalan Produksi } \\
\text { Skenario Pesimis }\end{array}$ & $\begin{array}{c}\text { Peramalan Produksi } \\
\text { Skenario Moderat }\end{array}$ & $\begin{array}{l}\text { Peramalan Produksi } \\
\text { Skenario Optimis }\end{array}$ \\
\hline 2019 & $1,395,666$ & $1,757,588$ & $2,119,511$ \\
\hline 2020 & $1,268,358$ & $1,770,083$ & $2,271,808$ \\
\hline 2021 & $1,179,293$ & $1,781,704$ & $2,384,115$ \\
\hline 2022 & $1,110,478$ & $1,792,508$ & $2,474,538$ \\
\hline 2023 & $1,054,775$ & $1,802,547$ & $2,550,318$ \\
\hline 2024 & $1,008,437$ & $1,811,870$ & $2,615,303$ \\
\hline 2025 & 969,193 & $1,820,526$ & $2,671,859$ \\
\hline 2026 & 935,529 & $1,828,559$ & $2,721,589$ \\
\hline 2027 & 906,377 & $1,836,011$ & $2,765,646$ \\
\hline 2028 & 880,946 & $1,842,923$ & $2,804,900$ \\
\hline 2029 & 858,629 & $1,849,331$ & $2,840,033$ \\
\hline 2030 & 838,950 & $1,855,270$ & $2,871,590$ \\
\hline 2031 & 821,528 & $1,860,774$ & $2,900,019$ \\
\hline 2032 & 806,052 & $1,865,873$ & $2,925,694$ \\
\hline 2033 & 792,262 & $1,870,595$ & $2,948,929$ \\
\hline 2034 & 779,944 & $1,874,969$ & $2,969,994$ \\
\hline 2035 & 768,916 & $1,879,018$ & $2,989,120$ \\
\hline 2036 & 759,023 & $1,882,767$ & $3,006,510$ \\
\hline 2037 & 750,132 & $1,886,236$ & $3,022,340$ \\
\hline 2038 & 742,128 & $1,889,447$ & $3,036,765$ \\
\hline 2039 & 734,913 & $1,892,418$ & $3,049,922$ \\
\hline 2040 & 728,400 & $1,895,166$ & $3,061,933$ \\
\hline 2041 & 722,513 & $1,897,709$ & $3,072,905$ \\
\hline 2042 & 717,187 & $1,900,061$ & $3,082,935$ \\
\hline 2043 & 712,362 & $1,902,236$ & $3,092,111$ \\
\hline 2044 & 707,988 & $1,904,248$ & $3,100,508$ \\
\hline 2045 & 704,019 & $1,906,109$ & $3,108,199$ \\
\hline
\end{tabular}

Sumber : Hasil Perhitungan ARIMAX $(1,2,2)$

\section{Sisi Produktivitas}

Sama halnya dengan pola produksi dan luas areal yang cenderung mengalami peningkatan selama periode 2019-2045, kondisi ini sejalan dengan tingkat produktivitas kakao yang naik, meskipun cenderung berfuktuasi. Secara umum, rata-rata produktivitas kakao di Indonesia pada periode tahun 2019-2045 diperamalan mencapai 54,4165. Hal ini dapat dilihat dari Gambar 9 dibawah ini. 


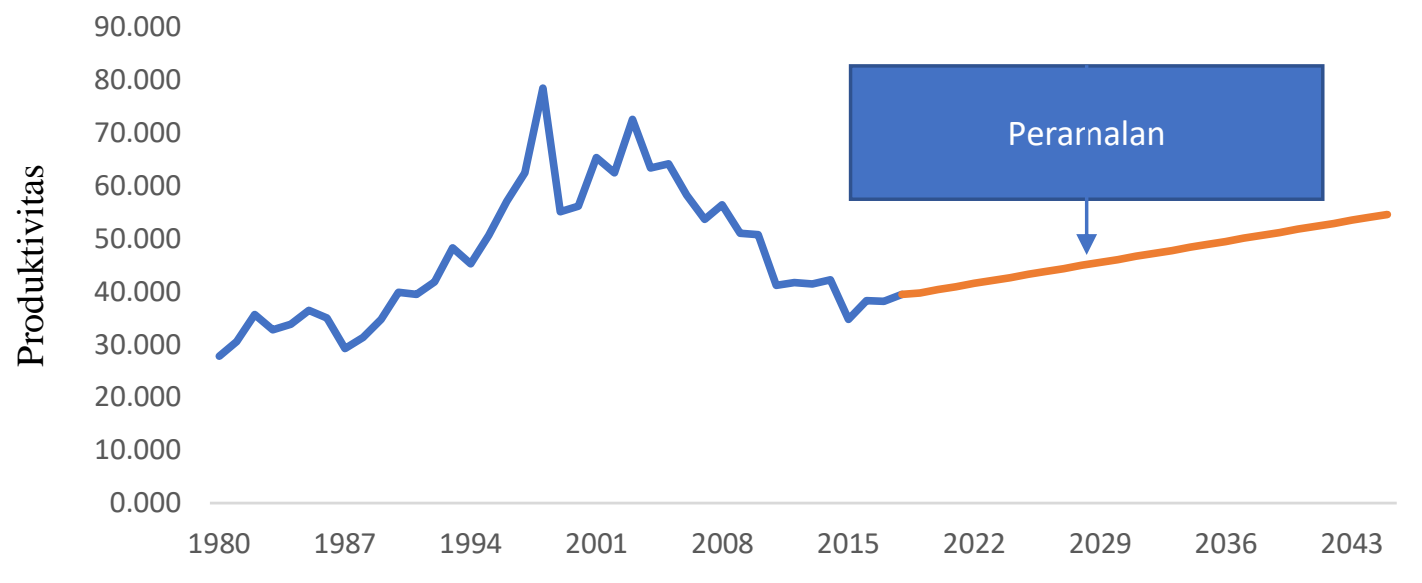

Tahun

\section{Gambar 12. Peramalan Produktivitas Kakao Periode Tahun 2019-2045}

Sementara itu, hasil peramalan skenario moderat pada derajat kepercayaan 95 persen menunjukkan bahwa produktvitas kakao di Indonesia pada tahun 2045 sebesar 54.034. Hal yang sama pada skenario optimis bahwa produktivitas kakao di Indonesia pada tahun 2045 terus meningkat, sedangkan hasil skenario pesimis menunjukkan hasil menurun pada tingkat 1.0004 . Lebih jelasnya dapat dilihat pada Tabel 12 dibawah ini.

Tabel 12. Peramalan Produktivitas Kakao Tahun 2019-2045 dengan Skenario Pesimis, Moderat dan Optimis

\begin{tabular}{|c|c|c|c|}
\hline Tahun & $\begin{array}{c}\text { Peramalan Produksi } \\
\text { Skenario Pesimis }\end{array}$ & $\begin{array}{c}\text { Peramalan Produksi } \\
\text { Skenario Moderat }\end{array}$ & $\begin{array}{c}\text { Peramalan Produksi } \\
\text { Skenario Optimis }\end{array}$ \\
\hline 2019 & 25.7446 & 39.387 & 53.7822 \\
\hline 2020 & 22.2395 & 39.763 & 58.5343 \\
\hline 2021 & 18.2306 & 40.387 & 63.6507 \\
\hline 2022 & 14.6666 & 40.941 & 68.3617 \\
\hline 2023 & 11.1650 & 41.514 & 72.9991 \\
\hline 2024 & 7.7604 & 42.082 & 77.5427 \\
\hline 2025 & 4.4065 & 42.652 & 82.0347 \\
\hline 2026 & 1.0938 & 43.221 & 86.4857 \\
\hline 2027 & 1.0912 & 43.790 & 90.9075 \\
\hline 2028 & 1.0909 & 44.359 & 95.3064 \\
\hline 2029 & 1.0891 & 44.928 & 99.6878 \\
\hline 2030 & 1.0809 & 45.497 & 104.0552 \\
\hline 2031 & 1.0800 & 46.066 & 108.4114 \\
\hline 2032 & 1.0781 & 46.635 & 112.7584 \\
\hline 2033 & 1.0772 & 47.205 & 117.0979 \\
\hline 2034 & 1.0733 & 47.774 & 121.4313 \\
\hline 2035 & 1.0712 & 48.343 & 125.7595 \\
\hline 2036 & 1.0688 & 48.912 & 130.0834 \\
\hline 2037 & 1.0673 & 49.481 & 134.4038 \\
\hline 2038 & 1.0655 & 50.050 & 138.7211 \\
\hline 2039 & 1.0590 & 50.619 & 143.0359 \\
\hline 2040 & 1.0412 & 51.189 & 147.3486 \\
\hline 2041 & 1.0393 & 51.758 & 151.6595 \\
\hline 2042 & 1.0211 & 52.327 & 155.9689 \\
\hline 2043 & 1.0136 & 52.896 & 160.2771 \\
\hline 2044 & 1.0122 & 53.465 & 164.5842 \\
\hline 2045 & 1.0004 & 54.034 & 168.8906 \\
\hline
\end{tabular}




\section{KESIMPULAN}

Ada beberapa hal yang dapat disimpulkan dari penelitian ini. Hasil peramalan (forecasting) terhadap produksi dan luas areal lahan lada selama periode 2019-2045 cenderung mengalami penurunan, sedangkan produktivitas lada cenderung stabil pada angka 0,48 ton per hektare. Sejalan dengan pola perkembangan produksi kopi Indonesia, peramalan terhadap produksi, luas areal kopi dan produktivitas juga terus mengalami peningkatan. Sementara itu, hasil peramalan terhadap produksi tebu meningkat, meskipun mengalami fluktuatif. Adanya fluktuasi tersebut antara lain tidak lepas karena masalah iklim, misalnya kemarau basah sehingga terjadi turunnya rendemen karena tebu yang dipanen bercampur dengan air. Secara umum, luas panen tebu di Indonesia diperkirakan kembali meningkat dan fluktuatif karena sangat dipengaruhi oleh pendapatan petani dan iklim. Peningkatan luas panen ini lebih disebabkan oleh adanya peningkatan pada luas panen tebu di Perkebunan Rakyat. Hal ini dikarenakan sebagian besar perkebunan tebu di Indonesia diusahakan oleh petani tebu rakyat dibandingkan kontribusi dari perkebunan tebu milik perusahaan (PBN atau PBS). Sama halnya dengan pola produksi dan luas areal yang terus mengalami peningkatan selama periode 2019-2045, kondisi ini sejalan dengan tingkat produktivitas tebu yang naik, meskipun cenderung lambat. Lambanya kenaikan produktivitas tersebut diduga karena adanya faktor iklim dan juga teknik budidaya.

Hasil peramalan terhadap kakao Indonesia menunjukkan bahwa produksi berfluktuasi dan cenderung meningkat. Terjadinya fluktuasi produksi kakao tersebut antara lain disebabkan karena harga biji kakao di pasar internasional sangat berfluktuasi. Sementara itu, hasl peramalan terhadap perkembangan luas areal kakao di Indonesia menunjukkan kecenderungan meningkat. Sama halnya dengan pola produksi dan luas areal yang cenderung mengalami peningkatan selama periode 2019-2045, kondisi ini sejalan dengan tingkat produktivitas kakao yang naik, meskipun cenderung berfuktuasi.

\section{REFERENSI}

Box, G.E.P., Jenkins, G.M., \&Reinsel, G.C. (2008). Time Series Analysis Forecasting and Control (4thEd.). Oakland: Holden-Day, Inc.

Cryer, J.D., \& Chan, K. (2008). Time Series Analysis With Application in R (2nd Ed.). New York: Springer.

Evans, K.P., \& Speight, A.E.H. (2010). Intraday Periodicity, Calendar and Announcement Effects in Euro Exchange Rate Volatility. Research in International Business and Finance, 24, 82101.

Lee, H. M., \& Suhartono. (2010). Calendar Variation Model Based on ARIMAX for Forecasting Sales Data with Ramadhan Effect. Proceedings of the Regional Conference on Statistical Sciences, 5.

Lee, M.H., \&Suhartono, S.(2010). Calendar Variation Model Based on ARIMAX for Forecasting Sales Data with Ramadhan Effect, Proceedings of the Regional Conference on Statistical Sciences 2010, (pp. 349-361). Malaysia: Universiti Teknologi MARA. 
Bayu Kharisma. Peramalan Indikator Mikro Kinerja Komoditas Strategis......

Lin, H., Liu, L., Tseng, Y., \& Su, Y. (2011). Taiwan's International Tourism: A Time Series Analysis with Calendar Effects and Joint Outlier Adjustments. International Journal of Tourism Research, 13, 1-16.

Pujawan, I. N., \& Mahendrawathi. (2010). Supply Chain Management, Edisi Kedua. Surabaya: Guna Widya.

Tersine, R. J. (1994). Principles of Inventory and Materials Management, 4th Edition. New Jersey: Prentice Hall.

Wei, W. W. S. (2006). Time Series Analysis: Univariate and Multivariate Methods, 2nd Edition. New York: Pearson. 